\title{
A Qualitative Study on Patience in Academic Life
}

\author{
Bilgen KIRAL ${ }^{* 1}$ (D) \\ ${ }^{1}$ Aydin Adnan Menderes University, Faculty of Education, Department of Educational Administration, Aydin, Turkey, \\ * Corresponding Author: bilgen.kiral@adu.edu.tr
}

\begin{tabular}{|c|c|}
\hline Article Info & Abstract \\
\hline $\begin{array}{ll}\text { Received: } & 28 \text { May } 2019 \\
\text { Accepted: } & 17 \text { July } 2019\end{array}$ & $\begin{array}{l}\text { This research was conducted to identify views of PhD students } \\
\text { regarding the concept of patience in academia. The research was } \\
\text { carried out with } 8 \mathrm{PhD} \text { students studying at a Faculty of Education in } \\
\text { Aegean Region in 2018-2019 academic years. Phenomenology, which is } \\
\text { one of the qualitative research approaches, was used in the study. The } \\
\text { participants were selected on a volunteer basis with criterion sampling, } \\
\text { convenience sampling and maximum variation sampling methods. The }\end{array}$ \\
\hline $\begin{array}{l}\text { Keywords: Patience, academia, } \\
\text { academic life, academic patience, } \\
\text { PhD student }\end{array}$ & $\begin{array}{l}\text { data was collected with semi-structured interview form created by the } \\
\text { researcher and analyzed with content analysis method. Validity, }\end{array}$ \\
\hline DOI:10.18009/jcer.570871 & $\begin{array}{l}\text { patience was addressed within the categories of finding a solution and } \\
\text { closing the case and education. The researcher has reached the }\end{array}$ \\
\hline Publication Language: Turkish & $\begin{array}{l}\text { conclusion that PhD students can show patience to courses/academic } \\
\text { studies, friends, academicians and physical environment; and showing } \\
\text { patience creates psychological, physical and familial effects as well as } \\
\text { effects on social life and effects related to friends. }\end{array}$ \\
\hline
\end{tabular}

open access (a) CrossMark (C)

To cite this article: Kıral, B. (2019). Akademik hayatta sabır üzerine nitel bir çalışma. Journal of Computer and Education Research, 7(14), 250-283. DOI:10.18009/jcer.570871

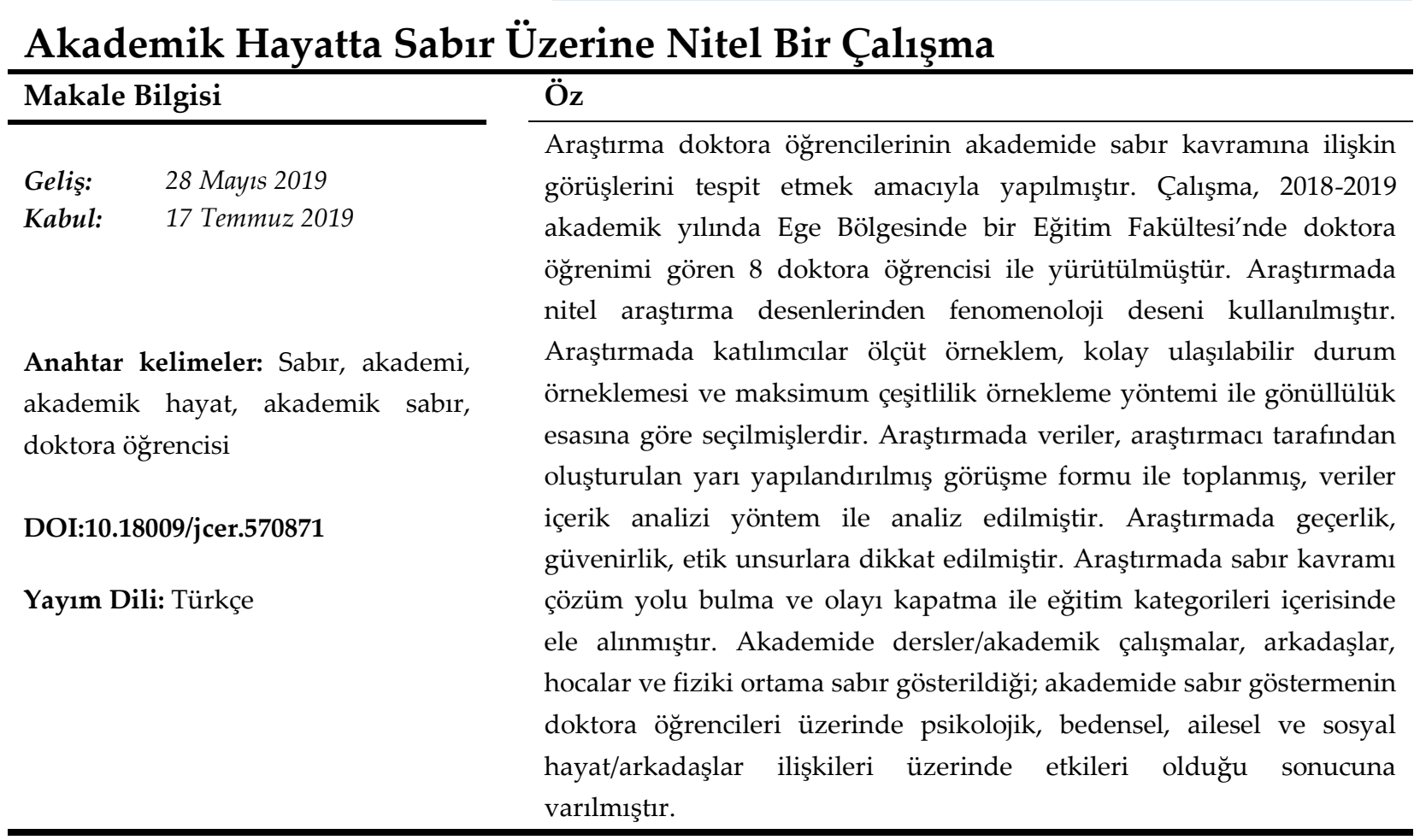




\section{Summary}

\section{A Qualitative Study on Patience in Academic Life}

\section{Introduction}

In daily life, patience is defined as the capacity to accept or tolerate delay, problem or suffering without getting angry or upset (Music, 2013). Schnitker (2012) defines it as "the propensity to wait calmly in the face of frustration or adversity". Patience is enduring trials and tribulations in social life (Okçu \& Pilatin, 2018), bearing with adverse conditions; and has five aspects. These are perseverance, tolerance of boredom, serenity, patient listening and comfort with delays (Lavelock, 2013). Schnitker (2012) mentions three types of patience. These are; (1) daily hassles patience, (2) Life hardships patience, (3) interpersonal patience. Patience can be shown in ordinary activities such as traffic congestion as well as in more important and long-term situations such as long-term diseases or attitude of mothers against their newborn babies. Interpersonal patience is defined as the person's tolerance to other persons in social relationships. For example, coping with a challenging person.

Upon reviewing studies on patience (such as Doğan, 2014; Dudley, 2003; Eliüşük, 2014; Okçu \& Pilatin, 2018; Özdemir, 2018; Schnitker, 2012), The researcher has not yet found any study aiming to introduce "opinions of PhD students on concept of patience". This may be the only study in this field, as can be seen from the review of body of literature. The researcher has decided to carry out a study on this subject, because of the fact that $\mathrm{PhD}$ students expressed in the conversations that they had to show patience to many people (especially academicians and doctorate friends) and situations during doctorate process. This study is significant, because of a lack of study on PhD students regarding patience and to find solutions for the situations in which PhD students show patience. The study aims to determine the opinions of PhD students on the concept of patience. The study searched for answers to below questions based upon this aim.

According to the PhD students:

1. What is academic patience?

2. What are the situations you show patience in the academy?

3. What are the reasons you show patience in the academy? 
4. What is the profile of the person you can bear with in the academy?

5. What are the effects of academic patience on you?

\section{Method}

This is a qualitative research which provides opportunity to work on few subjects in detail. Phenomenology approach was used for the purpose of addressing persons circumstances in interpreting the world (Patton, 2014). The research was carried out with 8 PhD students studying at Faculty of Education in Aegean Region in 2018-2019 academic years. Criterion sampling, convenience sampling and maximum variation sampling methods were used in the study. The criterion in this study were created by the researcher (Marshall \& Rossman, 2014).

First of all body of literature was reviewed and then a semi-structured interview form related to the subject was created for the research. Face-to-face interviews were conducted by the researcher with a tape recorder. Interviews recorded on the tape recorder were transcribed by the researcher. After data collection and transcription, analysis process began and content analysis methodology was used in analyzing the data. Methods such as participant verification, variation, expert's opinion, coding by different researchers, observation, interviewing, document analysis, use of direct quotations and code names in the research for validity (Creswell, 2002, 2007; Merriam, 2009; Patton, 2014). Miles and Huberman's formula (1994) was used for reliability. Another researcher coded the study and the conformity rate was $92 \%$.

\section{Findings and Discussion}

The research was conducted for the purpose of studying the patience of PhD students in the academic life. Two main categories are formed as a result of $\mathrm{PhD}$ students defining the concept of patience in the academy. These categories are finding a solution and closing the case, and education. The PhD students show patience against courses/academic studies, friends, academicians and physical environment. It was identified upon examination that patience is shown in consequence of education/academic studies, closing the case, necessity, student's serenity, love \& respect and previous experiences. The researcher has reached the conclusion that showing patience creates psychological, physical and familial effects as well as effects on social life and effects related to friends. 
Patience does not involve modifying a stimulus, but replying to and regulating the corresponding stimulus (Schnitker \& Emmons, 2007). Studies on coping mechanisms indicate that impatience is not a vital stressor; however, they assert that individual's response is important (Leahy, 2008). PhD students had to endure article writing process, delivery of the article to the journal and waiting for the reviewers' assessment, revising, another waiting period; or following the courses, homework, readings, data collection while writing the thesis and writing process as well as friends, academicians and family during PhD education. Student may encounter several adverse results, if he/she is not patient. For this reason, being patient in academia and behaving accordingly may be important both for the individual, his/her environment, institution he/she works for, and for the studies he/she carried out / will carry out. The research indicates that it is important for individuals' own health, relationships with family and friends and quality of academic studies that they are patient in order to achieve positive results. For this reason, individuals may determine strategies to establish and improve patience, and behave accordingly. Two persons collaborating in group studies and conducting group study with anyone he/she wishes shall secure justice in work load. Academicians using plagiarism detection tools (eg. turnitin), reading projects carefully and providing feedback, not discriminating between the students they consult and others when they grade their work and not reflecting individual complaints on the grades of the student etc. shall be useful for academic purposes. The results can be generalized by developing a patience scale in the study and applying to more PhD students. This study can be conducted with academicians or teachers and principals working in private or public schools. 


\section{Giriş}

Bireyler yaşamlarında can sıkıcı bir durum, morallerini bozan bir olay, ertelenme veya bekletilme gibi durumlarla karşılaştıklarında olumsuz bir takım duygular yaşayabilmektedirler. Her birey hayatın içerisinde bu ve benzeri gibi olayları tecrübe edebilmektedir. Bu olumsuz duygularla baş etmede sabırlı olmanın rolü olduğu söylenebilir. Bireyler sabırlı davranarak aslında birçok olası çatışma ya da sorunların üstesinden gelerek, sorunlarının etkilerini azaltabilirler. Yaşanan sorunların ve can sıkıcı durumların sağlık ve psikolojik iyi oluş üzerinde olumsuz etkileri vardır. Sabrın, bireyin yaşamında dönüm noktası olarak kabul edilen olayları daha olumlu tarafa ve olayların akışını tersine çeviren bir etkiye sahip olduğu görülmüştür (DeLongis, Coyne, Dakof, Folkman \& Lazarus, 1982). Sabır kavramı ile ilgili ilk akademik çalışmalar Blount ve Janicik'e (1999, 2000; Akt. Blount \& Janicik, 2001) ait olup, modellerini beş nitel araştırmaya dayandırarak iki makalede özetlemektedirler. Bununla birlikte, bu makaleler sabrı gecikmeye karşı bilişsel davranışsal ve duygusal tepki olarak tanımlamaktadır. İlk makaleleri, bireylerin sabırları ve sosyal gecikmelere karşı sabırsız tepkileri nasıl açıkladıklarını anlama girişimi (kişisel gecikmelere kıyasla); ikinci makale ise, duygunun sabır ve sabırsızlıktaki rolüne odaklanmaktadır.

Sabır Türk Dil Kurumu Sözlüğ̈̈̈'nde (2019); “Acl, yoksulluk, haksızlık vb. üzücü durumlar karşısında ses çıkarmadan onların geçmesini bekleme erdemi, dayanç"; Tasavvuf Terimleri ve Deyimleri Sözlüğü'nde (1997) Arapça'dan "sabr" olarak gelmekte ve "Başına gelen belalara, sıkıntılara dayanmaya sabır dendiği gibi, Allah'a ibâdette devam ve isyandan sürekli kaçma" ya da "sabır" denir. İngilizce'de ise "patience" sözcügüne karşılık gelen sabır; sinirlenmek veya kızmaksızın acılara, problemlere veya erteleme durumlarına karşı tolerans gösterme veya razı olma kapasitesine sahip olma, olarak tanımlanmaktadır (Oxford Sözlük, 2019).

Günlük yaşamda, sabır, sinirlenmeden veya alt üst olmadan, sorun veya gecikmeyi kabul etme veya tolere etme kapasitesi olarak kabul edilir (Music, 2013). Schnitker'a (2012) göre sabır, kişinin hayal kırıklığı, sıkıntı veya acı karşısında sakin bir şekilde bekleme eğilimi olarak kabul edilmektedir. Sabır, insanın sosyal hayatta karşılaştığı güçlüklere ve sıkıntılara göğüs germesi (Okçu \& Pilatin, 2018), bireyin olumsuz koşullara katlanmaya çalışması olup; beş yönü bulunmaktadır. Bunlar sebat etme, hoşgörülü ve can sıkıntısına karşı toleranslı olma, içsel huzurlu olma, sabır edilmesi gereken konuyu dinleme ve gecikme durumlarında rahat olmadır (Lavelock, 2013). Schnitker (2012) sabrı üç grupta incelemektedir. Bunlar; (1) 
gündelik yaşamda sabır (Daily hassles patience), (2) yaşam zorluklarında sabır (Life hardships patience), (3) kişiler arası sabırdır (Interpersonal patience). Trafikte bekleme gibi sıradan faaliyetler için sabır gösterilebileceği gibi, daha önemli uzun vadeli durumlarda da sabır gösterilebilmektedir. Ebeveynlik ciddi bir rahatsızlıkla başa çıkmak buna örnek olarak verilebilir. Veya zamanla ilgili olmayıp, kişilerarası ilişkiler sonucu, kişilere yönelik de sabır göstermek gerekebilir. Örneğin zor bir insanla başa çıkmaya çalışmak buna örnek verilebilir.

Curry, Price ve Price (2008), sabırlı bireylerin yaşadıkları problemler karşısında diğerlerine göre daha olumlu tutum sergilediklerini ve sorunlarla daha kolay başa çıktıklarını ifade etmektedirler. Aynı zamanda sabırlı kişiler diğerlerine göre daha fazla olumlu bakış açısına sahip olup; olumsuz bakış açısı ve kaygı düzeyleri daha düşüktür. Ayrıca; sabırlı bireyler sabırsız bireylere göre işbirliğine daha yatkındırlar. Sabır, bireylerin yaşadığı her türlü zorluk, tehdit ve kayıp karşısında gönüllü olarak dayanma, direnme, göğüs germe ve sonucu bekleme eğilimi olduğu için psikolojik bir süreçtir (Doğan \& Gülmez, 2014). Öyleyse sabır gösterme hem davranışsal (belirli bir bekleme olmasından dolayı), hem duygusal (kişinin sakin kalabilmesinden dolayı), hem de bilişsel bir kavram olup, psikolojik bir süreç olarak değerlendirilebilir (Doğan, 2014). Bu da sabrın doğuştan gelen bir kavram olmayıp; sonradan kazanılan bir durum olduğunun bir göstergesidir (Schnitker, 2012).

Toplantılar, pazartesi sabah trafiği, ağlayan çocuklar, uzun kuyruklar, mezuniyet törenlerini beklemek, sabah araba kornaları, akşam yemeği için patronu veya birilerini beklemek, geç gelen rötar yapan uçak veya tren, zamanlama değişiklikleri, konuşmayı bırakmayan iş arkadaşları veya diğer kişiler her biri sabır gösterilen durumlara örnektir. Sabır aslında birçok duruma sağlıklı bir cevap olarak kabul edilebilir. Çocuk sürekli ağlıyorsa, ebeveynler sabırlı davranır ve öfkeyle yaklaşmazlar. Sıra beklerken sabırlı olmak ve gecikmeli bir durum olduğunda öfke veya düşmanlıkla davranmamak, tepki göstermemek birçok negatif durumu engellemektedir. Bazı mesleklerde de tüm çalışma ortamları yüksek düzeyde sabır gerektirmektedir. Bunlar ilkokul öğretmenleri, özel eğitim öğretmenleri, terapistler, danışmanlar, denetmenler olarak sayılabilir (Dudley, 2003).

Blount ve Janicik'e (1999, 2000; Akt. Blount \& Janicik, 2001)göre hedefin gecikmesi de sabrı gerektirmektedir. Bu araştırmacılara göre iki tür gecikme mevcuttur. İlk gecikme türü, hedefin beklenen başarısı geri çekildiğinde hedefin ertelenmesinden kaynaklanır. Bu tür olayların örnekleri, bir uçağın havaalanından ayrılmasının gecikmesi, bir restoranda 
oturmanın gecikmesi veya bir bilgisayar programının yayınlanmasındaki gecikme veya bir kitabın yayınlanmasıdır. İkinci tür gecikme, hedefin engellenmesinden, birey bir şeyin sonucunu beklemek zorundadır. Blount ve Janicik'e (1999; Akt. Blount \& Janicik, 2001) göre biri hiç durmadan konuşurken veya kolikli bir bebek kesintisiz olarak ağladığında veya bir araba alarmı veya kornası gecenin ortasında çaldığında ve kapatılmadığında olabilir.

Sabır bir gecikme olduğunda ortaya çıkabilir. Gecikmenin doğası ve gecikmenin özellikleri, gecikmeye verilen tepkiyi anlamada önemli faktörlerdir (Blount \& Janicik, 2001). Gecikmeler aynı değildir. Gecikme aynı zaman diliminde olsa bile, iki kişi ilgili zamanın önemine bağlı olarak farklı tepkiler gösterecektir. Aynı kişi, aynı zaman miktarında bir gecikme yaşamakta bir durumda diğerinden daha farklı tepki gösterir. Gecikme durumlarındaki farklılık, gecikme zamanının uzunluğu ve süresinin bilinmemesi durumunda zamanın aciliyetinin, zamanın mevcudiyeti veya yetersizliğinin yanı sıra gecikme beklentisi ile de ilgilidir (Blount, 1995). Sabır göstermede, kişinin beklemeye karşı tutumu, bekleme ortamındaki dikkat dağıtıcıların varlığı, bekleme ortamı ve kişinin dikkatini dağıtma yeteneği önemli rol oynamaktadır Kendini kontrol etme, sosyal normlar ve kişinin kendi çıkarlarını değiştirme yeteneği, gecikmeye karşı tolerans göstermesi önemlidir (Dudley, 2003). Sabır edilen gecikme durumunda, birey bu gecikmeyi tanımladıktan sonra, onu değerlendirmelidir (Blount \& Janicik, 2001; Akt. Blount \& Janicik, 2001). Anahtar faktör, gecikmeye dâhil olan zamanın kişi için ne kadar değerli olduğudur. Diğer faktörler, gecikmenin beklenip beklenmeyeceğini ve gecikmenin uzunluğunun bilgisi olup olmadığını içerir. Bir gecikme meydana geldiğinde sonuç, kişinin beklediğini deneyimlemesidir (Dudley, 2003).

Sabrın bireysel faydaları olduğu gibi örgütsel faydaları da bulunmaktadır. Bu sebeple sabrın faydaları bireysel ve örgütsel faydalar olarak ikiye ayrılmaktadır. Bunlar aşağıda açıklanmıştır.

Bireysel faydalar: Sabırlı davranan birey hizlı ve ani karar vermek yerine rasyonel karar ve davranış sergileme eğilimindedir. Kişinin gecikmiş isteklerinin yerine getirilmesi ile başa çıkma yeteneği olumsuz sonuçlarla ters ve olumlu sonuçlarla pozitif yönde korelasyon gösterir (Comer \& Sekerka, 2014). Öyleyse kişi sabır göstererek oluşabilecek olumsuz olayları en düşük seviyeye indirebilir denilebilir. Sabrın olumsuz duygularla ve depresyonla ters ilişkili olduğunu ve sabır gösterilmediğinde baş ağrısı ve akne gibi psikosomatik semptomların (Schnitker \& Emmons, 2007) da tetiklendiğini söylemek mümkündür. Sorun 
yaşayan bireyler öfke ve çaresizlik tarafından tüketilmekte ve böylece yaşamı kısaltan hastalıklara neden olabilecek toksik duygular ve kronik stres ile karşı karşıya kalabilmektedirler. Sabır gösteren bireylerin ise psikolojik ve psikosomatik durumların yönetiminde daha etkili olduğu söylenebilir (Kıral, 2008). Ayrıca sabırlı olmanın, bireyin kendi içinde, artan hedef çabası, hedef memnuniyeti, düşük depresyon ve olumlu başa çıkma eğilimi gibi avantajlarını ve faydalarını da saymak mümkündür (Schnitker, 2012). Kısacası sabırlı olmak bireyin yaşamsal, sosyolojik, psikolojik ve fizyolojik sağlık durumunu olumlu etkilemektedir.

Örgütsel faydalar: Örgütsel gelişme ve büyüme için zor koşullarla sabırla baş etmek gerekir. Bu da kaliteyi artıran önemli bir unsurdur (Comer \& Sekerka, 2014). İşyerinde sabrın bir diğer potansiyel faydası, kişilerarası etkileşimleri daha da artırarak performansı yükseltebilmesidir (Pearson \& Porath, 2005). Sabrın bir diğer önemli örgütsel sonucu ise etik davranışın geliştirilmesidir. Hedeflere ulaşmak için algılanan ve gerçek baskılar karşısında hızlıca karar verenler, etik dışı seçimler yapma eğilimine girebilirler (Akrivou, Bourantas, Mo \& Papalois, 2011; Darley \& Batson, 1973). Ancak, sabırlı davrananlar, kasitlı olarak dürtüsel hareket etmek yerine, başkalarının ve örgütün önceliklerini dikkate alan doğru kararlar verip, kendi arzularını yükseltmek (Sekerka \& Zolin, 2007) yerine topyekün örgüt için olumlu kararlar alabilirler. Örgüt içerisinde günlük yaşam olaylarını kontrol etme davranışları da yine sabırla mümkündür (Burger \& Cooper, 1979). Kısacası sabırlı davranışların örgütsel faydaları örgütsel kaliteyi ve örgüt yaşantısında uzun süren refahı sağlama, örgütsel hoşnutluk ve verimlilik ile etik davranışların yerleşmesi olarak sayılabilir.

Sabır ile ilgili yapılan çalışmalar incelendiğinde (Doğan, 2014; Dudley, 2003; Eliüşük, 2014; Okçu \& Pilatin, 2018; Özdemir, 2018; Schnitker, 2012 gibi), “doktora öğrencilerinin sabır kavramına yönelik görüşlerini" ortaya koymayı amaçlayan bir çalışmaya henüz rastlanmamıştır. Sabır ile ilgili yapılan çalışmalar incelendiğinde örneğin Eliüşük (2014) tarafından yapılan çalışmada, lisans 1-2-3-4. sınıf öğrencilerinin öz-anlayış, öz-belirleme ve kişilik özellerinin sabır düzeylerini anlamlı bir biçimde yordayıp yordamadığını tespit etmek amaçlanmıştır. İlgili çalışma nicel araştırma yöntemleri kullanılarak yapılmıştır. Araştırmanın sonucunda sabır ile öz-anlayış arasında pozitif yönlü anlamlı ilişki bulunmuş; öz-anlayış, öz-belirleme ve beş faktörlü kişilik özellikleri ile ayrı ayrı ve birlikte değerlendirildiğinde sabrın tüm alt boyutlarını yordadı̆̆ı tespit edilmiştir. Doğan (2014) ise dindarlık, sabır ve psikolojik iyi olma arasındaki ilişkileri tespit etmek amacıyla nicel 
araştırma yöntemi ile yürüttüğü araştırmasında, dindarlık-sabır, sabır- psikolojik iyi olma ve dindarlık- psikolojik iyi olma arasında pozitif yönlü anlamlı ilişki olduğu sonucuna varmıştır. Özdemir (2018) tarafından yapılan çalışmada ise engelli ailelerindeki evli bireylerin evlilikte problem çözmeleri ile sabır gösterme davranışları arasında bir ilişki olup olmadığını tespit etmek amaçlanmıştır. Araştırmanın sonucunda evli bireylerin sabır gösterme davranışları ile problem çözmeleri arasında istatistiksel olarak pozitif yönde anlamlı bir ilişki olduğu sonucuna varılmıştır. Dudley (2003) yaptığı deneysel çalışmada dört haftalık sabır eğitimi sonunda erkeklerin kadınlardan daha sabırlı olduğu sonucuna ulaşmıştır. Okçu ve Pilatin (2018), 6 - 7 ve 8. sınıf öğrencilerin sabır değerini, resimlerle ifade etmelerini istemişlerdir. Öğrencilerin sabır algısını etkileyen en önemli faktörlerin; gerçek yaşam olayları, okul ortamı, kişiler arası ilişkiler, duyguların kontrolü ve dini olgu olduğu sonucuna ulaşmışlardır. Schnitker (2012) sabrın yüksek düzeyinin, depresyonun azalmasına ve kontrol durumuna bağlı olarak olumlu etkisinin artmasına yol açtığını tespit etmiştir.

Araştırmalardan da görüldüğü gibi doktora öğrencilerinin, doktora öğrenim sürecinde gösterdikleri sabrı araştıran bir araştırmanın olmaması araştırmayı önemli kılmaktadır. Alan yazın taramalarından da görüldüğü gibi bu alanda yapılan tek çalışma olduğu söylenebilir. Ayrıca bu konunun çalışma sebebi araştırmacının, doktora öğrencileri ile yaptığı güncel sohbetlerde doktora sürecinde birçok duruma ve kişiye sabır gösterdiklerini ifade etmeleri sebebiyle, araştırmacı bu konuyu çalışmaya karar vermiştir. Sabır konusunun doktora öğrencileri üzerinde çalışılmamış olması, bu konunun önemini ortaya koymakta, öğrencilerin sabır gösterdikleri konulara çözüm bulmak adına önem arz ettiği söylenebilir. Sayılan sebeplerden yola çıkarak araştırmada, doktora öğrencilerinin akademide sabır kavramına ilişkin görüşlerini tespit etmek amaçlanmıştır. Bu amaçtan yola çıkarak aşağıdaki sorulara yanıt aranmıştır.

Doktora öğrencilerine göre;

1. Akademik sabır nedir?

2. Akademide sabır gösterilen durumlar nelerdir?

3. Akademide sabır göstermelerinin nedenleri nelerdir?

4. Akademide sabır gösterilen insan profili nasıldır?

5. Akademik sabrın üzerlerindeki etkileri nasıldır? 


\section{Yöntem}

Araştırma, ayrıntılı olarak az kişiyle çalışma imkânı veren nitel araştırmadır. Kişilerin dünyayı anlamlandırma durumlarına eğilmek (Patton, 2014) amaciyla fenomenoloji deseni kullanılmıştır. Fenomenolojik çalışmalarda, kişilerin bireysel yaşam deneyimleri, günlük yaşantıları ele alınmaktadır (Ersoy, 2016; Merriam, 2009). Araştırmaya katılacak kişilerin olayla ilgili tecrübelerinin olması bu sebeple önemlidir. Bu tecrübelerin ne olduğu, nasıl deneyimledikleri ile ilgili bütünsel bir yaklaşım benimsenerek araştırma yürütülmüştür (Moustakas, 1994). Yapılan araştırmada fenomenoloji yaklaşımlarından betimleyici fenomenoloji yaklaşımı esas alınmıştır. Çünkü betimleyici fenomenolojide araştırmaya katılan bireylerin bildikleri şeyin ne olduğundan ziyade, onların deneyimlerinin ortaya konulması ve betimlemek önemsenmektedir (Ersoy, 2016). Betimleyici fenomenolojinin öncüsü Husserl'dır. Husserl'a göre fenomen, katılımcların deneyimlerine göre tanımlanıp, betimlenmektedir (Eddles-Hirsch, 2015).

\section{Katılımcilar}

Araştırma, 2018-2019 akademik yılında Ege Bölgesi'nde bir Üniversite'nin Eğitim Fakültesi'nde doktora öğrenimi gören 8 doktora öğrencisi ile yürütülmüştür. İlgili Üniversitenin Sosyal Bilimler Enstitüsü'nde kayıtlı 48 öğrenci, Fen Bilimleri Enstitüsü'nde kayıtlı 6 doktora öğrencisi bulunmaktadır. Bu öğrencilerden araştırmaya katılmaya gönüllü olan 8 kişi araştırmanın katılımcılarını oluşturmaktadır. Zaten Moustakas (1994) da fenomenolojik araştırmalarda araştırılan fenomene ait katılımcıların deneyimlerinin olması ve araştırmaya katılmaya gönüllü olmaları gerektiğini ifade etmektedir.

Araştırmada ölçüt örneklem, kolay ulaşılabilir durum örneklemesi ve maksimum çeşitlilik örnekleme yöntemi kullanılmıştır. Bu araştırmadaki ölçütler araştırmacı tarafından oluşturulmuştur (Marshall \& Rossman, 2014). Ölçütler; doktora öğrencilerinin araştırmayı yürüten araştırmacıdan ders almıyor olmaları, eğitim fakültesinde doktora yapıyor olmaları, en az bir dönem doktorada ders almış olmaları, öğretmen olmaları olarak belirlenmiştir. Araştırmacının bulunduğu fakültede, veri toplamanın diğer fakültelere göre rahat olması sebebiyle, kolay ulaşılabilir durum örneklemesi tercih edilmiştir (Bernard, 2011). Ayrıca araştırmaya katılan öğrencilerin ders/tez aşaması, evli/bekâr olma, cinsiyet, bölüm, yaş gibi birbirinden farklılık gösteren gönüllü katılımcılar tercih edilmesiyle de maksimum çeşitlilik örnekleme yöntemi kullanılmıştır (Creswell \& Clark, 2016; Ersoy, 2016). Araştırmaya katılan doktora öğrencilerine ait bilgiler Tablo 1'de verilmiştir. 
Tablo 1. Araştırmaya Katılan Doktora Öğrencilerine Ait Bilgiler*

\begin{tabular}{llllll}
\hline Kod ad & Yaş & Mesleki Durum & Öğrenim Durumu & Medeni durum & Çocuk Sayısı \\
\hline Yelda & 25 & Öğretmen & Ders Aşaması & Bekâr & - \\
Mahmut & 29 & Öğretmen/ Asistan & Tez Aşaması & Evli & 1 \\
Belma & 33 & Öğretmen & Tez Aşaması & Evli & 2 \\
Merve & 27 & Öğretmen & Ders Aşaması & Bekâr & - \\
Berksan & 39 & Öğretmen & Tez Aşaması & Evli & 2 \\
Remzi & 42 & Emekli Memur/ Öğretmen & Ders Aşaması & Evli & 3 \\
Selda & 36 & Öğretmen & Ders Aşaması & Evli & 2 \\
Aysun & 30 & Öğretmen/Asistan & Tez Aşaması & Evli & 1 \\
\hline
\end{tabular}

*Doktora öğrencilerinin hangi bölüm ve ana bilim dallarında öğrenim gördükleri bilgisi istekleri doğrultusunda gizli tutulmuştur.

Tablo 1'de görüldügü gibi araştırmaya 3 erkek ve 5 kadın; 4 ders ve 4 tez aşamasında, 2 bekâr 6 evli doktora öğrencisi katılmıştır. Evli olan katılımcıların çocuk sayısı 1 ile 3 arasında; araştırmaya katılan öğrencilerin yaş grupları incelendiğinde ise 25 ile 42 arasında değiştiği görülmektedir. Enstitülerden alınan bilgi doğrultusunda eğitim fakültesi ile bağlantısı olan 54 doktora öğrencisi olduğu tespit edilmiştir.

\section{Verilerin Toplanması ve Analizi}

Öncelikle alan yazın taranmış, ardından konuyla ilgili yarı yapılandırılmış bir görüşme formu oluşturulmuştur. Araştırmacı formu hazırlarken alanında uzman bir öğretim üyesinin görüşünü almış, bir doktora öğrencisi ile ön uygulama yapılmış, ardından forma nihai şeklini vermiştir. Formda yer alan sorular "Akademik sabır kavramı nedir, nasıl tanımlarsınız? Akademik hayatta sabrettiğiniz durumlar nelerdir?..." gibi sorulardan oluşmaktadır. Görüşmeler araştırmacının fakültedeki odasında, lisansüstü dersliği gibi boş, sessiz ve rahat mekânlarda gerçekleştirilmiştir. Görüşmelerin tümü yaklaşık 181 dakika sürmüştür. En uzun görüşme 41 dakika civarındadır. Araştırmada görüşmeye başlamadan önce katılımcılara kişisel bilgilerinin gizli kalacağı, isim ve bölüm bilgilerinin verilmeyeceği bilgisi verildikten sonra görüşmeler başlamıştır. Görüşmeler araştırmacının kendisi tarafından yüz yüze ve ses kaydı kullanmak suretiyle yapılmıştır. Ses kayıt cihazına kaydedilen görüşmeler araştırmacının kendisi tarafından yazıya geçirilmiş olup, görüşme dökümü 35 sayfa civarındadır.

Araştırmada 8 kişi ile görüşülmüş, diğer doktora öğrencileri şehir dışında olmaları, çalışma saatlerinin yoğun olması ve farklı sebeplerle araştırmaya katılmamışlardır. Ayrıca araştırmada 8 kişiden fazla kişi ile görüşülmemesinin diğer sebebi ise ifadelerin doygunluğudur. Araştırma kapsamında benzer cevapların verilmesi, araştırmada doygunluğa ulaşmak anlamına gelerek, görüşmelerin bitirilebileceği de araştırmacılar 
tarafından ifade edilmektedir (Lincoln \& Guba, 1985). Son görüşmelerde benzer ifadelerin olması sebebiyle farklı katılımcılarla görüşmeler yapılmamıştır. Nitel çalışmalarda seçilen örneklem sayısı ister bir ister, elli veya yüz olsun, örneklem için ana kural, bilgilerin doyuma ulaşması ve tekrar ifadelerin olmasıdır. Çünkü örneklem artık, geçmiş görüşmelerde yer alan verilerle benzeştiği için sayı yeterli olarak kabul edilmektedir (Morgan ve Morgan, 2008).

Burada doygunluğa ve veri toplamanın yeterli olduğu kanısına varıp, veri toplamayı durdurmaya araştırmacı karar vermektedir ve araştırmacı tekrarlar başladığı anda veri toplamayı bırakmalıdır (Onwuegbuzie \& Collins, 2007). Fenomenolojik çalışmalarda, araştırmaya dâhil olacak, olayı deneyimleyen katılımcılarla ilgili farklı araştırmacılar farklı yaklaşımlarda bulunmuşlardır. Örneğin Miles \& Huberman, (1994) en az 1 kişiyle, Creswell (2007) 3-4 ile 10-15 kişi arasında; Charmaz (2011) en az 10, Polkinghorne (1989) ise 5-25; Rubin ve Babbie (2016) 3-10 kişiyle çalışılmasını önermektedir. Buradan hareketle katılımcıların sayısının yeterli olduğu söylenebilir.

Veri toplama ve transkripsiyon (yazıya geçirme) işlerinin ardından araştırmanın analiz süreci başlamıştır. Araştırmada katılımcıların görüşleri frekanslar halinde verilmemiş, sadece liste halinde verilmiştir. Araştırmada gözlem ve görüşme yapılmış; veriler içerik ve doküman analizi ile çözümlenmiştir. Gözlemler araştırmanın başlangıcından bitene kadar devam etmiş olup; doğal gözlemler olup, ayrıca herhangi bir form hazırlanmamış, gerekli notlar alınmak suretiyle yapılmıştır. Doktora öğrencileri ile ilgili bir takım bilgiler ise enstitülerden alınmış olup, burada öğrencilerin bölüm bilgileri gizli tutulmuştur. Ardından toplanan veriler içerik analizi ile kod, kategori ve alt kategorilere ayrılarak (Yıldırım \& Şimşek, 2005) yapılmıştır.

\section{Geçerlik ve Güvenirlik Çalışmaları}

Araştırma kapsamında geçerlik için katılımcı doğrulatması yapılması, çeşitleme, uzman görüşüne başvurulması, farklı analizcilere kodlatma, gözlem, görüşme, doküman analizi, çalışmada doğrudan alıntılar kullanılması, kod adlar tercih edilmesi gibi yöntemler kullanılmıştır (Creswell, 2002, 2007; Merriam, 2009; Patton, 2014). Güvenirlik için ise Miles ve Huberman (1994) formülünden yararlanılmıştır. Miles ve Huberman (1994) hesaplanan uyum oranın \%80 olmasının güvenirlikte yeterli olacağını belirtmektedirler. Araştırma kapsamında, bir araştırmacıya daha kodlatma yaptırılmış, uyum oranı \%92 bulunarak araştırmanın ilgili araştırmacıların verdiği orana göre yeterli olduğu söylenebilir. 


\section{Araştırmactnın Rolü}

Araştırmacı araştırmaya başlarken kendi görüş ve önyargılarını araştırma dışında bırakarak araştırmasına başlamıştır (Yin, 2011). Katılımcıları kendi değer yargılarına, düşüncelerine göre yönlendirmekten kaçınmış (Lopez \& Willis, 2004), etik ilkeler doğrultusunda araştırmasını tamamlamıştır. Araştırmada katılımcıların kimlik ve bölüm bilgilerini gizli tutacağı bilgisini vermiş, katılımcılara kod adlar vererek araştırma içerisinde, doğrudan alıntıları kod adları ile vermiştir. Kod adlar Yelda, Mahmut, Belma, Merve, Berksan, Remzi, Selda ve Aysun'dur.

\section{Bulgular}

Araştırmanın bulguları beş başlık altında incelenmiştir. Bunlar akademik sabır kavramı, akademide sabredilen durumlar, akademide sabretme nedenleri, akademide sabredilen insanların özellikleri ve akademide sabretmenin üzerlerindeki etkileridir.

\section{Akademik Sabır Kavramı}

Araştırmaya katılan doktora öğrencilerine akademik sabır kavramını tanımlamaları istenmiş, onların verdikleri cevaplar neticesinde iki kategori oluşturulmuştur. $\mathrm{Bu}$ kategorilere ilişkin bilgiler Tablo 2' de verilmiştir.

Tablo 2. Akademik Sabır Kavramı

\begin{tabular}{|c|c|c|c|}
\hline \multicolumn{4}{|c|}{ Akademik Sabır Kavramı } \\
\hline \multirow{4}{*}{$\begin{array}{l}\text { Çözüm yolu } \\
\text { bulma }\end{array}$} & Mücadele etmek & \multirow{12}{*}{$\begin{array}{l}\text { Eğitimle } \\
\text { ilgili }\end{array}$} & Doktora=sabir \\
\hline & Süreci olumlu yönetmek & & Ekstra gelen iş yükü \\
\hline & Susmak & & Var olan iş yükü \\
\hline & Stres yönetimi & & Çalışmaların güçlüğü \\
\hline ve & Katlanmak/Alttan almak & & Sonuca ulaşmak \\
\hline olayı & Sessizlik & & Bıkmamak, sıkılmamak \\
\hline kapatma & Ani tepki vermemek & & Görev ve sorumluluğun üstesinden gelmek \\
\hline ile ilgili & Mantıklı davranmak & & Çalışmayı bitirmek \\
\hline & Hoşgörülü olmak & & Eğitim ortamındaki hocalar/arkadaşlar/diğer \\
\hline & Tahammül etmek & & insanlar \\
\hline & Kirmamak & & Sebat, azim, kararlılık göstermek \\
\hline & Anlayışla karşılamak & & \\
\hline
\end{tabular}

Tablo 2'ye göre akademik sabır kavramı eğitimle ilgili iki temel kategori belirlenmiştir. Bu kategorilerden ilki çözüm yolu bulma ve olayı kapatma ile ilgiliyken; ikincisi eğitimle ilgili olan kavramlardır. Aşağıda çözüm yolu bulma ve olayı kapatma ve eğitimle ilgili kategorilerine ilişkin görüşler verilmiştir.

*Akademide dersler, makaleler, zaman kısıtlılığı, ödev veya tez yetiştirme vb., hocaların gereksiz ve fazla istekleri, sorumsuz arkadaşlar gibi çeşitli dışsal etkilere karşı gösterdiğimiz tahammül gücü, sessizlik, tolere etme, anlayışla karşılama gücüdür (Belma). 
*Hemen ani bir tepki vermektense sonuçta aynı çatı altında yaşıyoruz sürekli birbirimizi göreceğiz $ı$ bunu hiçbir zaman unutmadan kırmadan $n$ mı mümkün olduğunca yapıcı bir şekilde süreci yönetebilmek diye düşünüyorum (Aysun).

*Eğitim süresince karşılaşılan sorunlarla mücadele edebilme süreci diye tanımlasam yerinde olur herhalde. Doktora eşittir sabır, daha doğrusu akademik eğitim sabır gerektiriyor zaten sabır olmazsa gerçekten de eee sonlandırmak mümkün değil çünkü bir sürü insanla karşılaşıyorsunuz bir sürü ayrı ayrı olayla karşılaşıyorsunuz hepsi sabır gerektiriyor (Berksan).

Görüldüğü gibi görüşmeye katılan katılımcılar hem eğitimle ilgili hem de olayı kapatma, çözüm yolu bulma ile ilgili cümleler kurmuşlardır. Bu sebeple ayrı başlıklar yerine, birlikte verme tercih edilmiştir. Buradan anlaşılan akademide sabır denildiği zaman hem eğitimle ilgili olan kavramlar hem de olayı kapatmak ve çözüm yolu bulmak ile ilgili kavramların fazlalığından dolayıdır.

Akademide Sabredilen Durumlar

Doktora öğrencilerine akademide sabrettikleri durumlar sorulmuş bunun neticesinde de Şekil 1'deki kategoriler oluşturulmuştur.

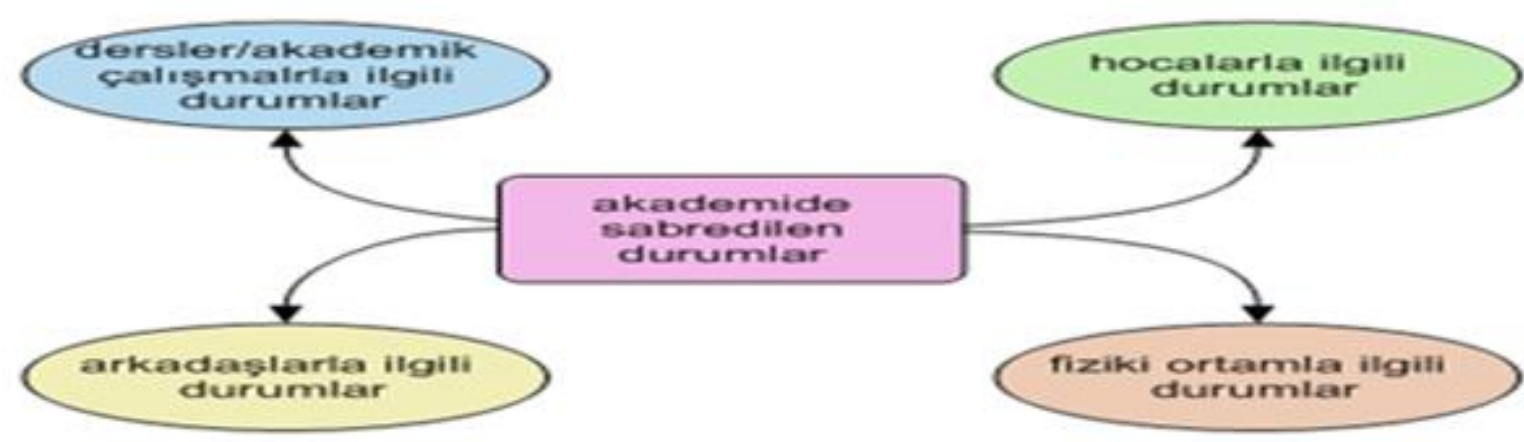

Şekil 1. Akademide sabredilen durumlar

Şekil 1'e göre akademide sabredilen durumlar dersler/akademik çalışmalarla ilgili sabredilen durumlar, hocalarla ilgili sabredilen durumlar, arkadaşlarla ilgili sabredilen durumlar ve fiziki ortamla ilgili sabredilen durumlar olmak üzere 4 kategoride toplanmıştır. Aşağıda bu kategorilere ilişkin alt kategoriler verilmiştir.

Dersler/Akademik Çalışmalarla İlgili Sabredilen Durumlar

Dersler/akademik çalışmalarla ilgili sabredilen durumlarda kendi arasında zaman baskısı, akademik çalışmalar, dersler ve ekonomik olmak üzere 4 alt kategoride incelenmiştir. Bunlara ilişkin kodlar Tablo 3'te verilmiştir. 
Tablo 3. Dersler/akademik çalışmalarla ilgili sabredilen durumlar

\begin{tabular}{ll}
\hline & Dersler/Akademik Çalışmalarla İlgili Sabredilen Durumlar \\
\hline \multirow{3}{*}{ Zaman baskısı } & Ders süresinin yoğun ve aralıksız olması \\
& Vakit darlığı \\
& İşi zamanında yetiştirme \\
& Dışarda farklı iş yapmaktan dolayı sıkıntı \\
& Yetişmeyecek kaygısı \\
\hline & Çalışma ve ödevlerin aynı ana denk gelmesi \\
& Makalelerin hakem ve yayım süresinin uzunluğu \\
Akademik & Veri toplarken yaşanan olumsuzluklar \\
çalışmalar & Okumaların fazla olması \\
& Çalışmalara gelen düzeltmeler \\
\hline \multirow{3}{*}{ Dersler } & Raporların kalitesizliği \\
& Rapor sayısının fazlalığı \\
& Arkadaşların sunumları \\
& AKTS’lerin düşük olması sebebiyle fazla ders alma \\
& Ders seçimi \\
\hline & Makale yayım ücreti \\
Ekonomik & Çeviri ücreti \\
& Sempozyum bildiri ücreti \\
& Aynı anda birçok kaynak alma
\end{tabular}

Tablo 3’te de görüldüğü gibi doktora öğrencileri dersler/akademik çalışmalar kategorisinde birçok duruma sabır göstermek zorunda kaldıklarını ifade etmişlerdir. Zaman baskısının içerisinde vakit darlığı, işi zamanımda yetiştirememe gibi; akademik çalışmalar kategorisinde okumalar, veri toplama, makale süreci gibi; derslerle ilgili bazı raporların kalitesizliği, raporların fazlalığı, ders seçimi gibi; ekonomik durumlar içerisinde bildiri, çeviri, makale ücretlerinin fazlalığı gibi durumlara sabır gösterdiklerini ifade etmişlerdir. Aşağıda her bir kategoriye ilişkin sırasıyla görüşlere birer tane örnek verilmiştir.

*Ders süresinin yoğun ve aralıksı olmasına sabır göstermek zorundayız. Örnek veriyorum ee salı günleri sabah sekiz buçuktan akşam beş buçuğa kadar aralıksız dersimiz var aralarda 15er dakikalık aralar yemek yemek için dahi firsatımız olmuyor. Ya da bir mola verip kendimize gelmek için bir firsatımız olmuyor. Bu konuda biraz sabır göstermemiz gerekiyor. Derslerimiz yoğun olduğu için sabır göstermemiz gerekiyor (Remzi).

*Hoca doktora ders aşamasında iki tane makale oluşturmamızı istemişti ama bu çok ă̆ır birşey bunun yanında ödevler de veriyordu iki-üç kere karşılaştım böyle bir durumla. Hocam yani yaptığın uygulama bence yanlış bir tane olsun çok nitelikli birşey çıkaralım demek istiyorsun ama diyemiyor sabrediyorsun (Aysun). 
*Derslerin yoğunluğuna sabır gösteriyorum mesela geçen dönem 12 rapor yazdım sabırla yazdik okuduk (Selda).

*Belli bir geliriniz var yani ders aşamasında bir derste mesela 5-6 tane kitap altyorsunuz.

Olması gereken şeyler biz burda bunu sürece yaymadı̆̆ımız için.... makale yayınlanacak oluyor bunun tabi çevirileri vs. oluyor bir makalemiz yayınlandı mesela yurt dışında yani adamlar bizim çevirimizi beğgenmiyor yani çevirimizi Ingiltere'de Amerika'da yaşamış hocalarla yapıyoruz yok onu da beğenmiyorlar yani tekrardan çevirmene ekstradan para bu da mali yük oluyor (Berksan).

\section{Hocalarla İlgili Sabredilen Durumlar}

Hocalarla ilgili sabredilen durumlar 3 alt kategoriye ayrılmıştır. Bunlar hocanın kişiliği ve davranışları, hocaya hayır diyememe ve hocanın değerlendirmeleri olarak başlıklandırılmıştır. Oluşturulmuş bu alt kategoriler aşağıda Tablo 4'te verilmiştir.

Tablo 4. Hocalarla İlgili Sabredilen Durumlar

\begin{tabular}{ll}
\hline & \multicolumn{1}{c}{ Hocalarla İlgili Sabredilen Durumlar } \\
\hline Hocanın kişiliği & Hocanın ilgisizliği \\
ve & Hocanın hayata bakış açısı \\
davranışları & Hocanın empati eksikliği \\
& Hocanın sadece mail/mesaj ile iletişim kurması \\
& Hocanın genel tarzı \\
& Hocaların tek işimizin doktora olduğunu düşünmeleri (farklı bir hayatımızın, \\
& işimizin olduğunu göz ardı etmeleri) \\
& Hocanın konuşmaları \\
& Hocanın tepkileri \\
& Hocanın siyasi görüşleri ile ilgili çalışmaların ders kapsamında inceletilmesi \\
\hline & Hocanın bahane kabul etmemesi \\
& Hocanın istediği gün ve saatte arayıp iş vermesi \\
& Hocayı eleştirememe \\
Hocaya & Dr unvanını/özerliğin olmaması \\
hayır & Jürilerde sıkıştırılmak \\
diyememe & Ekstra iş vermesi \\
& Hocaya bir gün benim de işim düşer düşüncesi \\
\hline Hocanın raporlarla ilgili özensizlikleri \\
Nota itiraz edememek \\
Ayocanın & Ayrımcılık yapması \\
Hocanın görüşlerini mecburen kabullenmiş gibi görünme \\
Adaletsiz değerlendirmeler (ödev/sunum vb) \\
Herkesin (hakeden/etmeyen) ders geçmesi/mezun olması \\
Hocaya yakın olanın/biat edenin iyi not alması \\
\hline
\end{tabular}


Tablo 4'te görüldüğü gibi hocanın kişiliği ve davranışları alt kategorisinde hocanın ilgisizliği, hocanın konuşmaları, tepkileri, kendini yenilememesi, hayata bakış açısı vb; hocaya hayır diyememe alt kategorisinde hocanın bahane kabul etmemesi, hocayı eleştirememe, jüriler, ekstra iş verilmesi vb; hocanın değerlendirmeleri kategorisinde ise hocanın verdiği nota, ödeve itiraz edememek, hocanın ayrımcllık yapması, adaletsiz değerlendirmeleri vb. sayılabilir. Aşağıda bu alt kategorilere ilişkin görüşler birer tane olmak üzere sırasıyla verilmiştir.

*Her hocanın kendine özgü bir siyasi görüşü muhakkak vardır benim de var herkesin var ancak bunun derste dikte edilmesi, bunun ders haline getirilmesi, katılsak ya da katılmasak da buna sabretmek zorunda kalıyoruz. Bunun sonuçları ne oluyor derseniz hocanın belirlediği tavsiye görüşe ilişkin birçok makaleyi alı incelemek değerlendirmek ve derste bunu paylaşmak durumunda kalıyoruz (Remzi).

*Hocaların bize genelde orda araştırma görevlisi olarak çalışıormuşuz gibi düşüncesi var. Başka işimiz yokmuş gibi. Ekstra bir işimizin olduğunu, ekstra bir hayatımızın olduğunu göz ardı ediyorlar. Bu tamamen hocalarla ilgili karşılaştığım problemlerden biri sabır gösterdiğim (Berksan).

*Yoğunluğumuzun olduğunu bildiğgi halde hocalarımızın bazıları eee bir iş daha verilebiliyor. Herhangi farklı bişey olabiliyor ekstra bir iş yükü olabiliyor bizim için. Zaten ekstra bir iş yükümüz var bir yoğunluğumuz bitmemiş bir işimiz var yazdığımız ya da okumamız gereken bişey mutlaka oluyor zaten hiç boş kalmıyoruz o yönden...... Öyle bişey öyle olduğunda hani kendi karakterimden dolayı da hayır diyemiyorum Hayır diyemediğim için tamam hocam olur hocam yaparız onların işini aldığım zaman bu sefer kendi yapmam gereken işi öteliyorum. Kendi yapmam gereken arkada kalıyor bu sefer onlarnnkini öne alıyorum mecbur hani böyle bir ikilemde kalıyorum (Mahmut).

*Adalet konusu aslında. Ee daha çok çalışan birinin daha iyi değerlendirilmesi gerektiğini düşünüyorum. Bizde burası böyle bir basamak gibi görülüyor. Evet başka işi var yapamadı diyoruz veya kamu da çalışan öğretmenler çok yoğun anliyoruz ama bence buraya zaman ayıramayan biri buraya gelmemeli. Biz burda en üst düzeyde doktora eğitimi almayı düşünüyorsak herkesin ayn çabayı göstermesi lazım. Yani buraya gelen herkesi muhtemelen mezun edecekler bırakmayacaklar. Böyle bir anlayış yok. Bu hem eğitimin kalitesini düşürüyor hem de öğrenciler arasında haksizlığa sebep oluyor hocalarm bu tutumuna katlanmak zorundayiz (Yelda).

\section{Arkadaşlarla İlgili Sabredilen Durumlar}

Doktora öğrencilerinin arkadaşları ile ilgili sabrettikleri durumlar 2 alt kategoriye ayrılmıştır. Bunlardan birincisi ödevler/akademik çalışmalar ile ilgili sabredilen durumlar iken; ikincisi arkadaşların kişiliği ve davranışları ile ilgili sabredilen durumlardır. Bunlara ilişkin olarak oluşturulmuş olan kodlar Tablo 5'te verilmiştir. 
Tablo 5. Arkadaşlarla İlgili Sabredilen Durumlar

\begin{tabular}{ll}
\hline Arkadaşlarla İlgili Sabredilen Durumlar \\
\hline & Tartışma ortamının olmaması/ Ödevlerin eleştirilememesi \\
& İyi ödevin gereksiz olduğu düşüncesi \\
& Ödevlerin teslim gününde yetişmemesi \\
& Çalışmalarla ilgili sorumsuzluklar \\
& Ortak çalışmalar \\
& İş görev dağılımı adaletsizliği \\
& Yeterince okumamaları \\
& Yoğunluktan dolayı gerilim \\
& Aile ile sorunlar \\
& Kaliteli ödev/sunum yapmamaları \\
& Danışmana herşeyin şikayet edilmesi \\
& Arkadaş olma mecburiyeti \\
& Gereksiz sohbetler \\
& Empati yapmamaları \\
& Umursamazlıkları \\
& İletişim kopukluğu \\
& Hocaya iyi görünmeye/yaranmaya çalışmaları \\
\hline
\end{tabular}

Tablo 5'te görüldüğü gibi arkadaşlarla ilgili sabredilen durumlar alt ketegorisinde ödevler/akademik çalışmalar kategorisinde akademik tartışma ortamının olmaması, ortak çalışmalar, çalışmaalrla ilgili sorumsuzluklar, iş-görev dağılımı adaletsizliği, kaliteli ödev/sunum yapmamaları vb. sayılırken; arkadaşların kişiliği ve davranışları alt kategorisinde danışmana herşeyin şikayet edilmesi, umursamazlıkları, hocaya iyi görünmeye çalışma vb. sayılmaktadır. Aşağıda bu iki alt kategoriye ait görüşler birer örnek olmak üzere sırasıyla verilmiştir.

${ }^{*}$ Grup çalışmalarında, ortak çalışmalarda yine herkesin ayrı bir işi olduğu için arkadaşlarla ilgili olarak sabır gösterdiğim durumlar oldu. Görev dă̆̆lımı yapıllyor mesela bir makale yazılacak veya bir ödev hazırlanacak veya bir bildiri sunulacak Bu belli aşamalarda paylaşıllyor. Deniliyor ki sen kendi kurumunda şu şu öğrencilere şu testleri uygula ben kendi kurumumda şunları uygulayayım sonra onları birarada toplayalım değerlendirelim analizini yapalım raporlaştıralım sen giriş bölümünü yaz ben yöntem kısmın yazayım diğeri bulgulardan şuraya kadar yazsın işte sonuç kısmını beraber yazalım. İşte bu gibi durumlarda eee bazen işler sekteye uğradı. Yani ee kimi arkadaş o anda düğün var ona gideceğim, ailemde şöyle bir sorun var onu halledicem veya hocaya söylesek daha sonra yapsak, söylesek daha ileri vakite teslim edelim gibi şeylerle karşılaştık. Bunun gibi. Tabiki eeee böyle durumlarda ben kendime düşen payı yaptım herşey hazır fakat teslim etme aşamasında edemiyorum çünkü karşı taraf ki insanın da aynı şeyi yapması lazım ki birleştirelim zamanında verelim eee dolayısıyla orda puan olarak veya değerlendirme olarak sıkıntı yaşamamak için bazı durumlarda arkadaşımızın işlerini de kendimizin yaptı̆̆ı oldu. Çünkü zamanında verme açısından.....(Berksan). 
*Benim raporunda kabul ediliyor ve aynı notu alıyor kopyala yapıştır yapılarak getirilen kötü bir rapor da aynı notu alıyor ve siz buna itiraz edemiyorsunuz. Çünkü siz itiraz edince birşeye yaramayacak aksine ters tepki göreceğiniz için mecburen susuyorsunuz ve güzel olmuş elinize sağlık diyorsunuz mecburen. Ama aslında olayın iç yüzü öyle değil. Bir çok şeye aslında sabretmek zorunda kalıyoruz. Bu aslında mükemmeliyetçilik değil aslında tamamen olması gereken şeyi istiyoruz çalışan daha yüksek puan alsın çalışan daha başarıl olsun ve el üstünde tutulsun ama o şekilde ilerlemediğini düşünüyorum. Yani biraz daha kişisel biraz daha biat etmeye dayalı aslında yani kim daha çok itaat ederse o dah iyi puan alıyor. Kim daha yakınsa hocaya o daha iyi yerde oluyor. Aslında bunlar olmamasi gereken şeyler buna sabretmek zorundayız (Yelda).

Fiziki Ortamla İlgili Sabredilen Durumlar

Doktora öğrencilerinin fiziki ortamla ilgili sabrettikleri durumlar iki alt kategoride incelenmiştir. Bunlar doktora dersi için derslik planlanmamış olması ve planlanmış olan dersliğin genel özelliklerinden kaynaklanan durumlardır. Aşağıda Tablo 6'da fiziki ortamla ilgili sabredilen durumlara ilişkin kodlar verilmiştir.

Tablo 6. Fiziki Ortamla İlgili Sabredilen Durumlar

\begin{tabular}{ll}
\hline & Fiziki Ortamla İlgili Sabredilen Durumlar \\
\hline & Hocanın odasında ders yapmak \\
& Odanın küçük ve kalabalık olması \\
Derslik planlanmaması & Kitaplar kucakta ders yapmak \\
& Projeksiyon olmaması \\
& Oturacak yerin dar ve sınırlı olması \\
& Ortam kaynaklı bedensel ağrılar (bel, kol vb) \\
\hline \multirow{3}{*}{ Planlanmış olan } & Bilgisayar donanımlı sınıf olmaması \\
dersliklerin genel & Sınıf düzeninin yetersizliği \\
özellikleri & Sadece bir oda olması \\
& Fiziki ortam yetersizlikleri (camın olmaması, , temiz olmaması, kapı kolu \\
& kırı, kaloriferin bozuk, klima bozuk olması gibi) \\
\hline
\end{tabular}

Tablo 6'da görüldüğü gibi fiziki ortamla ilgili sabredilen durumlar doktora için derslik planlanmaması alt kategorisinde yer alan hocanın odasında ders yapmak, hocanın odasında projeksiyon, oturacak yer vb. olmaması şeklinde sayılabilir. Planlanmış olan dersliklerin genel özellikleri ise temiz olmaması, kalorifer olmaması, fiziki ortamdan kaynaklanan bir takım yetersizliklerin olması şeklinde sıralanabilir. Aşağıda bu alt kategorilere ilişkin birer örnek sırasıyla verilmiştir.

*Doktora eğitiminde bizim bölüme planlanmış bir derslik henüz yok derslik olmadığı için de hocalarn odasinda rahatsiz ortamlarda ders görmek zorunda kalıyoruz sunumlar aktaracă̆ımız bir projeksiyon yok açıkçası oturabileceğimiz sandalye bile bulmakta zorluk çekiyoruz bu öğrenme ekosistemi açısında çok olumlu değil. Bir hocanın dersinde ben de tam 
koltuğun köşesine denk geldim onu örnek vereyim akşam bel ağrısından duramamıştım. Çok rahatsız edici oldu buna da katlanmak sabretmek zorunda kalmıştım (Remzi).

*Geçen dönem (derslik vardı) kapalı bir oda vardı şikayet ediyorduk sürekli burası çok havasız, kapall, pis, camsiz.. bu dönem onu da arar olduk. Ee belli bir sinıf ortamının olmaması öğrenmeyi etkiliyor ya da konsantre olamıyorsunuz ya böyle diken üsütünde gibi hocanın odasında kucağımızda kitap hocanın odasında sıkış tepiş ee o da etkiliyor motivasyonunuzu fiziksel koşullarda sabrımızı deniyor (Selda).

\section{Akademide Sabır Gösterme Nedenleri}

Doktora öğrencilerine akademide sabır gösterme nedenlerinin neler olduğu sorulmuş, bunun neticesinde de alt kategoriler oluşturulmuştur. Yapılan içerik analizinde toplam 6 alt kategorinin oluşturulmuştur. Akademide sabır gösterme nedenleri aşağıda Şekil 2 'de verilmiştir.

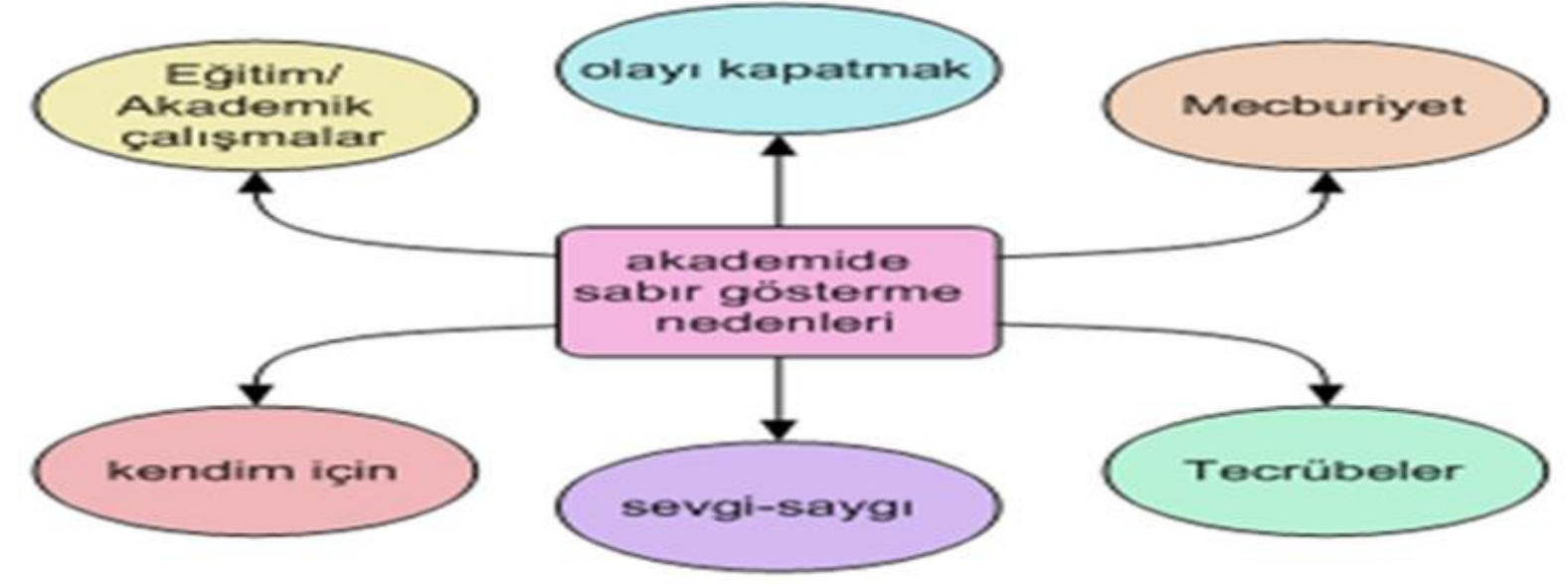

Şekil 2. Akademide sabır gösterme nedenleri

Şekil 2'de görüldüğü gibi akademide sabır gösterme nedenleri eğitim/akademik çalışmalar nedeniyle, olayı kapatmak için, mecburiyetten, kendim için, sevgi-saygımdan, tecrübelerimden dolayı şeklindedir. Bu alt kategorilerin her birinin de kendi içerisinde çeşitli kodlar yer almaktadır. Bu alt kategorilere ilişkin kodlar Tablo 7 'de ayrıntılı olarak verilmiştir. 
Tablo 7. Akademide sabır gösterme nedenleri

\begin{tabular}{|c|c|}
\hline \multicolumn{2}{|r|}{ Sabır Gösterme Nedenleri } \\
\hline $\begin{array}{l}\text { Eğitim/ } \\
\text { Akademik } \\
\text { Çalışmalar }\end{array}$ & $\begin{array}{l}\text { Başarı elde etmek, ilerlemenin eğitimle olması } \\
\text { Yapılanların faydalı olması/ Kişiye katkı sağlaması } \\
\text { Akademinin mutlu etmesi } \\
\text { Veri toplamak çalışmayı/tezi bitirtecek düşüncesi } \\
\text { İtibarlı bir dergiden gelen dönütlerle çalışmanın yayımlanacağı düşüncesi } \\
\text { İyi bir dergiye hakemlik yapmış olmak } \\
\text { Öğrenmek, araştırmak, okumak, kişisel gelişim }\end{array}$ \\
\hline $\begin{array}{l}\text { Olayı } \\
\text { Kapatma }\end{array}$ & $\begin{array}{l}\text { Kavga, çatışma ortamından kaçınmak istemek } \\
\text { İnsanlarla uğraşmak istememek } \\
\text { Süreci olumlu yönetmek }\end{array}$ \\
\hline Mecburiyet & $\begin{array}{l}\text { Ailenin beklentisi } \\
\text { “Ezile ezile yukarıya çıkacağız” düşüncesi } \\
\text { Usta-çırak ilişkisini kabullenmek } \\
\text { Arkadaşların danışmanlarına veya hocalara şikâyet etmemeleri için } \\
\text { Özerkliğe ve Dr unvanına sahip olmamak } \\
\text { Hocanın sürekli karşısına çıkacağı düşüncesi (yeterlik, kadro, doçentlik vb) } \\
\text { Okulu bitirmek } \\
\text { Bir yerlere gelmek } \\
\text { Dersi geçmek } \\
\text { Hiyerarşik bir durum olması/Hocaların üst konumda olması } \\
\text { Arkadaşlarla iletişim kurmak zorunda olmak (ortak ödev, materyal paylaşımı vb) } \\
\text { İşin bitirmek }\end{array}$ \\
\hline Kendim İçin & $\begin{array}{l}\text { Hayatı akademiye bağlamak/Hedefin bu olması } \\
\text { Bir-iki yılım kaldı katlanayım düşüncesi } \\
\text { Kişisel iç huzur } \\
\text { Akademide çatışma yaşamamak } \\
\text { Çatışmaları özel hayatıma yansıtmamak } \\
\text { Kendini rahat hissetmek } \\
\text { Can sıkıntısı ile iş yapmayı istememek } \\
\text { İş doyumu için } \\
\text { O işe de kafa yormamak için }\end{array}$ \\
\hline Sevgi-Sayg1 & $\begin{array}{l}\text { Hocalara saygıdan } \\
\text { Hoca ile ara bozulmasın diye/ Hocayla zıtlaşmamak için } \\
\text { Arkadaşları ve diğer insanları kırmamak için } \\
\text { Hocaya fikrini açıklamanın ters tepki yapabileceği endişesi } \\
\text { Hocaya işini öğretmiş gibi olmamak için }\end{array}$ \\
\hline Tecrübe & $\begin{array}{l}\text { Bugün hocanın bana işi düşmüştür, yarın benim de ona işim düşer düşüncesi } \\
\text { Tecrübelerden dolayı normal olduğunu düşünme } \\
\text { Görüş farklılığı olabileceğini bilmek } \\
\text { Karşıdaki kin tutup beni takıntı haline getirebilir düşüncesi } \\
\text { Çözüm olmayacağına inanmak } \\
\text { Sonuç getirmeyeceğini düşünmek } \\
\text { İşin mutlaka biteceğini, tamamlanacağını bilmek } \\
\text { Sabırsı olmanın işe yaramayacağını bilmek } \\
\text { O işi/olayı/kişiyi değiştiremeyeceğimi bilmek } \\
\text { "Yes man” olmak, hayır diyememek } \\
\text { Empati yapmak }\end{array}$ \\
\hline
\end{tabular}

Tablo 7'de de görüldüğü akademide sabır gösterme nedenleri başarı elde etmek, öğrenmek, çalışmayı sevmek, eğitimin/yapılanların faydalı olduğunu bilmek gibi nedenlerle eğitim/çalışmalar alt kategorisinde; kavga/çatışma yaşamak istememe, insanlarla uğraşmak istememe gibi nedenlerle olayı kapatma alt kategorisinde; dersi geçmek için, bir yerlere 
gelmek için, hiyerarşinin olması, Dr. unvanının olması gibi nedenlerden mecburiyet alt kategorisinde; hedefimin akademik kariyer olması, kendi iç huzurum için, iş doyumum için, bir-iki yıl kaldı katlanayım düşüncesi kodlarında kendim için alt kategorisinde; hocalara saygımdan, arkadaşları kırmamak için, hocalarla zıtlaşmamak için kodlarında sevgi-saygı alt kategorisinde; hayır diyememek, sonucu değiştiremeyeceğimi bilmem, önceki tecrübeler kodlarında tecrübe alt kategorisinde yer almaktadır. Her bir kategoriye ilişkin birer görüş aşağıda sırasıyla verilmiştir.

*Verileri toplamak benim tezimi bitirtecekse bana ben ona sabrederim. Bana SSCI bir makaleden dönüt geldiyse dünya kadar, makro değişiklikler yapmamı isteseler de yapmaya çalışırım sabrederim çünkü o iyi bir yerde yayımlanacak. Yine güzel bir yerden hakemlik teklifi geldiyse aslında bana para ya da başka bir şey olarak bir getirisi yok ama vakit ayırrrım sabrederim çünkü okurken bana bir katkı sağlar hem de iyi bir dergi ye hakemlik yapmış olurum (Aysun).

*Kavga çatışma ortamından kaçınmaya çalışıyorum mümkün olduğunca. Kimseyle çatışmaya girmek istemiyorum hani benim için istemediğim bir şey de olsa o çatışmadan kaçınmak için kabul ediyorum bazen. Hani uğraşmak istemiyorum. Dedim ya hocam "yes man"lik var bizde hocam hayır diyemiyoruz çatışma çıkacak yoksa (Mahmut).

*Doktora da bir hocamın sürekli beni demotive edici söylemleri ve bakışları beni oldukça rahatsı ediyordu. Ama bir şekilde sürekli karşıma çıkacağın bildiğim için sürekli sustum. Hocalara saygımdan, yeterlikte, kadro alırken, doçentlikte karşıma çıkabileceği ihtimali, hoca ile aram bozulması diye sabrediyorum daha doğrusu söylemek istediğim şeyler oluyor ama susuyorum susmak zorundayım, bitirmek bir yerlere gelmek istiyorsam sabırl olmak ve hocalarla iyi geçinmek zorundayım (Belma).

*Bu yola baş koydum daha doğrusu. Bütün hayatımı buna bağladım daha önce sağlık problemleri olduğu oldu sağllk kaybı yaşadım vaz geçsem herhalde o zaman vazgeçerdim ama bu işi başarmak istiyorum bu yüzden akademisyen olmak için girdim bu yola çok pes etmeyi düşündüm aslında zorluklarla karşılaştım ama sonuna kadar götürmem lazım hem kendim için hem ailem için çünkü okuyan bir kardeşim var yani bir an önce mesleğe atılip ona da yardımo olmak istiyorum. Babam hala çalışıyor emekli değil bir fabrikada çalışıyor maddi olarak da beni zar zor okutuyorlar ve artık bir şeylerin sonucunu da görmelerini de istiyorum o yüzden hedefim bu. Sabret nedenim hedefimin bu olması (Yelda).

*Dersi geçmek için, okulu bitirmek için, insanları kırmamak için, çatı̧̧ma yaşamamak için .....yani özellikle hocalarla ilgili karşılaştığımız sorunlar da kesinlikle öyle oluyor. Konuşmamızın başında anlattığım o sorunda hocaya gidip madem ödev verecektiniz o şekilde değerlendirecektiniz baştan bizi sinavla değerlendirdiniz arkadaşları proje ile ...daha düşük notla geçtik hem de daha başarılı olarak dersten. Çünkü biz daha iyi anlamışız ki finalde geçtik diğer arkadaşlarsa bütde... hani o şekilde mesela gidip hocaya söylemedik. Hocanın öyle bir şeyden haberi yok mesela. Neden hocaya belli bir saygımız var. Hocada ters tepki yapabilir, sen bana değerlendirmeyi mi öğretiyorsun diyebilirdi belki. İlişki bozulabilirdi. Kırmamak için de bir anlamda kendisini. Öyle bir şey söylemedim (Berksan).

*Daha zor durumları da yaşadığım için şimdi daha sabırlıyım sakinleştim. Bir de alışkanlık oldu, normalleşti bu yaşantı. İlk zamanlarda gösterdiğim tepkilerle şu anki farkl. Bu zaten 
her zaman olan bir olay yeni başıma gelen bir olay değil deyip, düşünüp öyle davranıyorum.

Kabullenme mi oluyor artık bilmiyorum geri çekilme, sessizleşme oluyor (Merve).

\section{Akademide Sabır Gösterilen Kişiler ve Bu Kişilerin Özellikleri}

Doktora öğrencilerinin akademide sabır gösterdikleri kişiler ve onların özelliklerinin neler olduğu sorulduğunda; sabır gösterilen kişilerin hocalar, arkadaşlar ve diğer kişiler olarak üç alt kategoriye ayrılmıştır. Bu üç alt kategorinin özellikleri de olumlu, olumsuz ve nötr özellikler olarak incelenmiştir. Aşağıdaki Tablo 8'de sabır gösterilen kişiler ve bunların özelliklerine ilişkin bilgiler yer almaktadır.

Tablo 8. Sabır Gösterilen Kişiler ve Bu Kişilerin Özellikleri

\begin{tabular}{|c|c|c|c|}
\hline & Hocalar & Arkadaşlar & Diğer Kişiler \\
\hline \multirow{3}{*}{$\begin{array}{l}\bar{\Xi} \\
\bar{\Xi} \\
\bar{\Xi} \\
0\end{array}$} & Hoca oldukları için saygımdan & Küçük çocuğu olup & Yoğun çalışan \\
\hline & Hocalar iyi niyetli & yetiştiremeyen & Değer verdiğim insanlar \\
\hline & Hocalar hoşgörülü & Arkadaşlar güvenilir & Kırmak istemediğim insanlar \\
\hline \multirow{23}{*}{$\begin{array}{l}N \\
\text { Dै } \\
\Xi \\
\Xi \\
O\end{array}$} & Agresif, ani çıkışları olan & Sevmediğim olumsuz & Kırıc1 \\
\hline & Negatif & davranışları olan & Patavatsiz \\
\hline & Empati yapmayan & Kendini beğenmiş & Adaletsiz \\
\hline & Öğrenciyi çok üst düzeydeymiş gibi & Sorumsuz & Bencil \\
\hline & gören & Fedakâr olmayan & Kendini öven \\
\hline & Çalışanla çalışmayanı ayırt edemeyen & Rahatına düşkün & Kendini üstün tutmaya çalışan \\
\hline & Dikkatsiz ve özensiz & Herhangi bir sorunu doğrudan & Sürekli bir şey bildiğini iddia \\
\hline & İntihale falan önem vermeyen & hocasına şikayet eden & eden \\
\hline & Ödevleri okumayan & Sorunları hocalara yanlış & Bir şey bilmeyen ama bildiğini \\
\hline & Geri bildirim vermeyen & aktaran & sanan \\
\hline & Değerlendirmede adaletsiz olan & Niteliksiz rapor hazırlayan & Boş insanlara \\
\hline & Eleştiriye açık olmayan & Dedikoducu & Aşırı özgüvenli \\
\hline & Bizim görüşümüzü dikkate almayan & Arkadan iş yapan & Israrc1 \\
\hline & Gereksiz isteği olan & Bencil & Empati yoksunu \\
\hline & Gereksiz boş şeyler isteyen & Herşeye alınan & Düşüncesiz \\
\hline & Bilmediği halde biliyormuş gibi & Herşeyi başka yere çeken & Karşısındakini zor duruma \\
\hline & yapan & Tembel & sokan \\
\hline & Dersine zamanında gelmeyen & Kirilgan & \\
\hline & Kendini yenilemeyen (10 yıl önceki & Yanlış anlamaya müsait & \\
\hline & bilgilerini kullanan) & Gergin arkadaşlar & \\
\hline & Çocuksu davranan & & \\
\hline & Önyargilı & & \\
\hline & Haksızlık yapan & & \\
\hline \multirow{4}{*}{ : } & Hayata bakış açısı benimkinden farklı & Bana sabredenlere sabrediyorum & Yakın ilişiklerimizin olmadığ 1 \\
\hline & hocalar & & Üst taraftaki (unvan) insanlar \\
\hline & Fazla isteği olan & & Doğrudan konuşamayacağımız \\
\hline & İletişim kurmak zorunda olduğum & & \\
\hline
\end{tabular}

Tablo 8 incelendiğinde akademide sabır gösterilen kişilerin öncelikli olarak hocalar ardından arkadaşlar ve son olarak da diğer kişiler olduğu sonucuna varılmıştır. Bu kişilerin 
özellikleri ise olumlu özellikler, olumsuz özellikler ve nötr olarak sınıflanmıştır. Aşağıda bu alt kategorilere ilişkin örnekler verilmiştir.

*Hoca olduğu için saygı duyduğumdan eee iyi niyetli olduğunu düşündüğüm için hoşgörrülü olduğunu düşündü̈̆̆̈̈m için (Selda).

*Hoca geliyor mesela derse diyor ki. Şunlar şunlar yapılacak...hocanın söylediği şekilde yapmak gerçekten uğraş gerektiriyor ama kimisi de mesela son iki günde birşeyler hazırlayıp apar topar veriyor mesela. Değerlendirmeye bakıyoruz sonra mesela eeee uğraşan 90 almış, uğraşmayan da 90 almış, 85 almış gibi. eee yani aradaki bu 5 puan için ben yani belki de 20 günümü verdim. Yani bu olmamall. Adaletsizliğe sabrediyorsun ama hoşuna da gitmiyor hatta şununla da yeri geliyor karşılaştık. Ŭ̆raşmayan 95 almış, uğraşan 85 almış o durumlarla da karşılaşıı̆̆ımız da oldu. Bu durumlarda tabi hoca mesela intihal raporları falan mesela dikkat etmesi gerekir. Bazı ödevler oluyor 40'ar sayfa 50'şer sayfa oturup yazıyoruz hani. Hoca hepsini okuması lazım, ayrı ayrı okuyup değerlendirmesi lazım, geri bildirim veriyor ama vermeyen de var o şekilde. Veriliyor ödev ondan sonra biz sadece not olarak görüyoruz bak senin ödevinde şuralarda eksik şuralar şöyle olmuş bundan dolayı senin puanını kırdım tarzında bir şey yok. Geri bildirim vermeyen var (Berksan).

*Sorumsuz, bencil, arkadaşlara daha çok oluyor, fazla isteği olan, gereksiz isteği olan hocalara yoksa dediğim gibi her hafta yansı yazdıran hocanın verdiği zor gelmiyordu yani gereksiz boş boş şeyler istiyorsa insanı rahatsız ediyor ya da kendi bilmediği halde bilmiş gibi davranıyorsa bu çok rahatsız edici ya dersine zamanında gelmiyorsa, 10 yıl önce öğrendiği şey kendisini hoca yenilemesi gerek, bir de hocam ben çocuksu davranışları çok sevmiyorum. Yani böyle her şeye alınmak herşeyi başka yerlere çekmek, daha olgun bir yapım olduğu için sonuçta ben 29 yaşındayım biraz daha yaşının gerektirdiği karaktere sahip olan, çalışkan insanlarn seviyorum aksi durumlar olduğunda canım siklliyor yine de sabrediyorum sabretmek zorunda kaliyorum (Aysun).

*Israrcı insanlar, birazck empati yoksunluğu olabilir karşıdakinin zor duruma girip girmediği konusunda empati yoksunluğu olabilir, hocam. Üçüncüsü onların yoğunluklarn olabilir. Kendi yoğunluklarını aşmak için bu şekilde çözüm buluyorlar herhalde yoğunluklarıyla başedebilmek için hocalarımız bazen bizden yardım istiyorlar gerçekten yoğun oluyorlar o yüzden bizden yardım istiyorlar (Mahmut).

*Şikâyetçi, dedikoducu insanlara karşı sabretmeyi tercihe diyorum. Yani benim şikâyet edildiğim hocayla bunu ortak bir platformda görüşebilsek fikirlerimizi paylaşabilsek. Benim yanlış bir tarafım varsa bana söylense ben de eksik ve yanlı̧̧ gördü̆̆̈̈m hususlarn görüşüp sonuca bağlayabilsem az önce de dediğim gibi sonuç getirmeyeceğine inandiğım dedikodudan dolayı yanlış aktarımları içime sinmese de sabretmek zorunda kalıyorum. Arkadaşlarımla ilişkilerimde zaman zaman (Remzi).

*Öncelikle kırıcl, patavatsız, adaletsiz davranan çoğunlukla bencil insanlara genellikle kendini öven üstün tutmaya çalşan insanlara ki bu insan tipini hiç sevmiyorum hiç bişey bilmeyip sürekli bişey bildiğini iddia eden tipler vardır ya. Siz de evet evet dersiniz ya aslında ortada bişey yoktur boş, yani o özgüvenin arkası boş zaten çok bilen insan o kadar çok konuşmaz o tür insanlara pek tahammülüm yok yani ben de şey var nunı çalışan insana değer veriyorum açıkçası felsefem o biraz belki kötü gelebilir ama kulağa çalışmayıp senle aynı konumda olup da hiçbir şey bilmeden sana sürekli iddia ederek anlatması beni rahatsız ediyor insan bildiği kadar konuşmalı, okuduğu kadar bana cevap verebilmeli ya da kendini o şekilde övmelisin bu tip insanlara burada sabretmek zorundayım (Yelda). 
*Sabır gösterdiğim kişiler mutlaka benim çok değer verdiğim kişilerdir yoksa normalde çok sabırlı bir kişi değilimdir yani. Birisine sabır gösteriyorsam mutlaka değer verdiğim içindir, kırmamak içindir (Merve).

Akademide Sabrm Etkileri

Doktora öğrencilerine akademide sabır göstermelerinin üzerlerindeki etkileri sorulmuş, bunun sonucunda 4 kategori oluşturulmuştur. Doktora öğrencilerinin görüşlerine göre akademide sabrın etkileri Şekil 3'te verilmiştir.

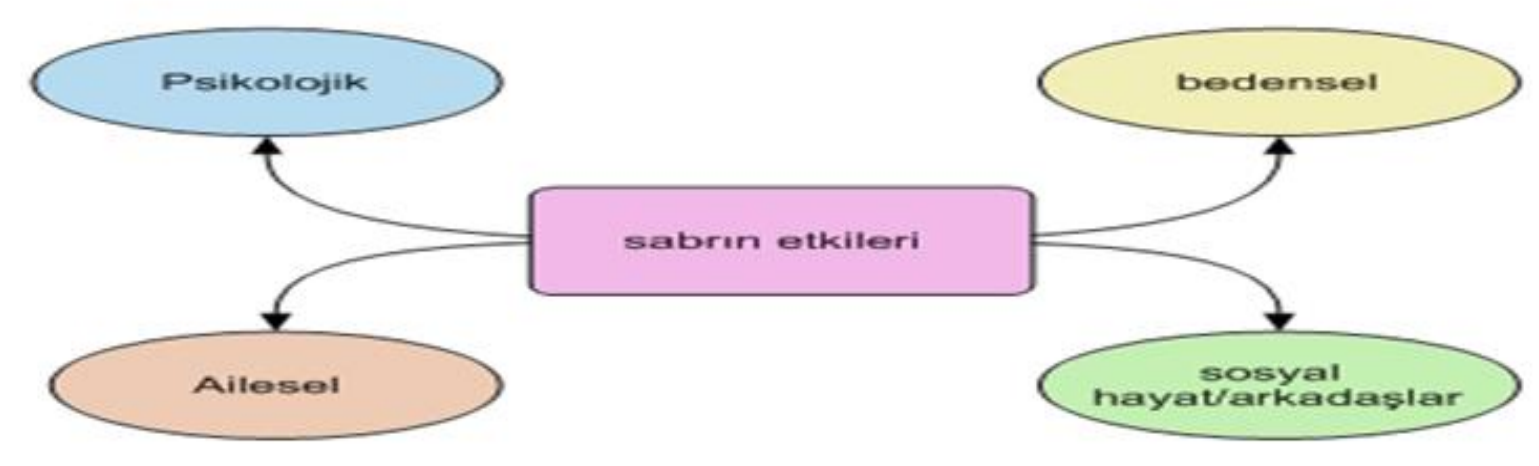

Şekil 3. Akademide sabrın etkileri

Şekil 3'te görüldüğü gibi akademide sabır göstermenin doktora öğrencileri üzerinde psikolojik, bedensel, ailesel ve sosyal hayat/arkadaşlar ile ilgili etkileri olmak üzere 4 kategori oluşturulmuştur. Ve her kategori altında alt kategoriler ve kodlar yer almaktadır. Bunlara ilişkin alt kategori ve kodların yer aldığı bilgiler Tablo 9, 10,11 ve 12' de verilmiştir. 
Tablo 9. Akademide sabrın psikolojik etkileri

\begin{tabular}{|c|c|c|c|}
\hline \multicolumn{4}{|c|}{ Psikolojik Etkileri } \\
\hline İçsel & $\begin{array}{l}\text { Tükenmişlik } \\
\text { Uğraşmamalıyım, çalışmamalıyım } \\
\text { düşüncesi } \\
\text { Ruhen ve psikolojik olarak yıpranma } \\
\text { Stres } \\
\text { Yalnızlaşma isteği } \\
\text { Sessizlik/Susmayı tercih etme } \\
\text { İçinden geldiği gibi davranmama } \\
\text { Kendi kendine kızma } \\
\text { Sabrın tükenmesi } \\
\text { Sürekli düşünceli olma } \\
\text { İçe kapanma ve içine atma } \\
\text { Asabiyet } \\
\text { Öğrenmeyi, derse yoğunlaşmayı ve } \\
\text { dikkati olumsuz etkileme } \\
\text { Görüş belirtememekten sıkılma } \\
\text { Üzüntü } \\
\text { Kızgınlık, öfke, gerilme } \\
\text { Kırgınlık } \\
\text { Psikoloji rahatsızlıklar }\end{array}$ & $\begin{array}{l}\text { Dişsal- } \\
\text { davranışsal }\end{array}$ & $\begin{array}{l}\text { Vazgeçme eğilimi } \\
\text { Ağlama } \\
\text { Görüşlerini açıklamaktan, itiraz } \\
\text { etmekten vazgeçme } \\
\text { Bildiklerini dışarıya yansıtmama } \\
\text { Öfke kontrolünü öğrenme } \\
\text { Argo kullanma } \\
\text { Ani sinirlenme/Ani patlama } \\
\text { Karşıdakini kırmaya dönük } \\
\text { davranışlar } \\
\text { Sözel saldırganlık } \\
\text { Siniri dışa vurma/Asabi olma } \\
\text { İnsanları tanıma/ İnsanlara nasıl } \\
\text { davranması gerektiğini öğrenme } \\
\text { Muhabbet etmek istememe }\end{array}$ \\
\hline
\end{tabular}

Tablo 9'a göre akademide gösterilen sabrın birey üzerindeki psikolojik etkileri içsel ve dışsal-davranışsal olmak üzere ikiye ayrılmıştır. İçsel etkiler üzerinde tükenmişlik, kızgınlık, öfke, sessizlik, yalnızlaşma, yıpranma, öfke gibi etkiler mevcutken; dışsaldavranışsal etkiler içerisinde argo kelimeler kullanma, ani sinirlenme, ağlama, Görüşlerini açıklamaktan, itiraz etmekten vazgeçme gibi etkilerin olduğu doktora öğrencileri tarafından ifade edilmiştir. Aşağıda bu alt kategorilerde yer alan görüşlere örnekler verilmiştir.

\footnotetext{
*Ben çok üst düzey sinirlenebiliyorum bu durumda sinirlendiğim zaten beni tabii ki çok yıpratıyor bu durum biraz şey eee karşımdaki insanı kırmaya yönelik tavırlar gösterebiliyorum. Sözel bir saldırganlık durumu hâkim oluyor bende. Bu durum beni sonradan çok etkiliyor. Bazen söylemek istemediğim şeyleri de söylüyorum arkadaşlarıma karşı da oluyor. Bazen aileme karşı da oluyor. Sonradan hem üzülüyorum sabır sınırımı tüketip böyle davrandı̆̆ım için (Merve).

*Psikolojik olarak öğrenmemi olumsuz etkiliyor diyebilirim dikkatimi yoğunlaşmamı olumsuz etkiliyor çünkü itiraz etmem gereken bir görüş belirtmem gereken bir durumda görüşememek sabretmek durumunda kaldığımda istemsizce dikkatim dağılıyor artık kendimi tekrar derse veya öğrenmem gereken her neyse artı ona veremiyorum kendimi onu hissediyorum (Remzi).
} 
Akademide gösterilen sabrın bireyin bedeni-fizyolojisi üzerinde de bir takım etkilerinin olduğu doktora öğrencilerinin görüşleri sonucunda ortaya çıkmıştır. Bunlar Tablo $10^{\prime}$ da verilmiştir.

Tablo 10. Akademide Sabrın Bedensel-Fizyolojik Etkileri

\begin{tabular}{ll}
\hline \multicolumn{2}{c}{ Bedensel-Fizyolojik Etkileri } \\
\hline Saçların beyazlaması & Migren/ Baş ağrısı \\
Yorgunluk/ Çöküntü & Yaşlanma \\
Uyuyamama/Uykusuzluk & Çay kahve tüketiminin artması sonucu gerginlik \\
Gözde spazm (seğirme) & Yemek yemeyi erteleme/unutma \\
Sürekli bir şeyler yeme isteği/ Kilo alma & Açlıktan vücudun olumsuz etkilenmesi \\
Sürekli gece oturarak çalışmaktan hantallaşma & Uçuk, sivilce \\
\hline
\end{tabular}

Tablo 10'a göre akademide gösterilen sabrın uykusuzluk, gözde spazm, migren, uçuk/sivilce çıkması, yemek yememe, sürekli birşeyler yeme isteği gibi bedensel-fizyolojik etkileri olduğu tespit edilmiştir. Aşağıda bunlara örnekler verilmiştir.

*Yaklaşık aralık ayından beri, kasım ayından beri sol gözümde bir şey var spazm diyorlar buna. Daha doktora gidemedim. Seğirme hocam aralık kasımdan beri devam ediyor yeterlikten beri devam ediyor, o zaman başladı. Gece uykusuzluğu stres derken başladı ondan sonra da geçmedi, bir doktora gitme firsatım da olmadı açıkçası. Bazen çok seğiriyor bilgisayara çok kullanıyoruz gözlükte var sabrın yarattığı stres sonucunda olduğunu düşünüyorum (Mahmut).

*Ben de mesela uçuk falan çıkıyor dudağımda uçuk çıkar genelde ya da sivilce falan oluyor. Yani burada sabretmemiz gereken çok fazla şey olduğu için oluyor (Aysun).

Ama orda işte evdeki kendi çocuklarımızı eşimizi ihmal etmeden eee onlara da vakit ayırarak, işimizi ve aynı zamanda akademik çalışmaları yürütmek zorunda kaldık ama ben burda nasıl başardım bir ben bir de Allah bilir. Uykumdan fedakârlık yaparak daha çok yaptım. Çoğu zaman 2-3 saatlik uyku ile durduğum zamanlar oldu bu şekilde sabrı o şekilde gösterdim (Berksan).

Akademide gösterilen sabrın bireyin sadece kendi üzerinde etkisi olmadığı doktora öğrencileri tarafından ifade edilmiştir. Aileleri üzerinde de bir takım etkilerinin olduğu sonucuna rastlanmıştır. Aile üzerindeki etkilerine ilişkin bulgular Tablo 11'de verilmiştir. 
Tablo 11. Akademide Sabrın Ailesel Etkileri

\begin{tabular}{ll}
\hline & \multicolumn{1}{c}{ Ailesel Etkileri } \\
\hline & Aileye ilgi göstermemek \\
& Aileden/çocuktan uzaklaşmak veya uzaklaşmayı istemek \\
Olumsuz & Aileye vakit ayırmamak \\
davranışlar & Çocuklara olumsuz davranmak \\
\hline & En küçük şeyde çatışma çıkarmak/Evde sinirli davranmak \\
& En değerlilere sabır gösterememek \\
& Söylemek istemediği şeyleri söylemek \\
& Çocuklara asabiyet göstermek \\
& Ani çıkışlar, yüksek ses \\
& Gergin olduğu/olumsuz konuştuğu için aileden şikâyet almak \\
& Çocuk akşam vakit geçirmek isteyince olumsuz laflar söylemek \\
Elumsuz söylemler stres yaşamak & Sorunları aileyi üzmemek için paylaşmamak \\
& Evde yalnızlığı seçmek (erkeklerde mağara metaforu) \\
Eş ile paylaşmamak \\
Eşin olumsuzluklardan sıkılması ve paylaşmak istememesi \\
\hline
\end{tabular}

Tablo 11'de görüldüğü gibi akademik sabrın aile üzerindeki etkileri katılımcıların görüşleri doğrultusunda üç alt kategoriye ayrılmıştır. Bunlar olumsuz davranışlar, olumsuz söylemler ve paylaşmama olarak başlıklandırılmıştır. Aşağıda alt kategorilere ilişkin sırasıyla örnek ifadeler verilmiştir.

*...Yani kendi kendime geriliyorum. Çok fazla sabır gösterdiğim zaman benim iç dünyama olumsuz yansiyabiliyor ee evde çocuklara yansıtabiliyorum bunu ee onlara biraz daha sinirli davranabiliyorum çünkü bitiyor artık sabır. Onlara patlayabiliyorum. Haketmiyorlar ama onların nazımı çekeceğini düşünerek evde stres yapıyorum. Çok fazla sabır göstermekte aslında bu anlamda olumsuz etkileri oluyor kendine ve çocuklarına zarar veriyorsun. Sinirli davranıyorsun (Selda).

*Akademide gösterdiğim sabrın eve yansıması asabiyete daha fazla dönüşebiliyor. Çocuklara sabır kalmıyor çünkü. Tabii ki orda kendi çocuklarımız baba hadi şunu yapalım dediğinde yapmayalım.... daha sonra gönlünü alsak da bir çıkış ani bir yüksek ses, ses yükselmesi yaşadığım zamanlar oldu...... şekilde yine hani ilgi gösterememe daha az ilgi gösterme (Berksan).

*Aileme muhtemelen vardır... zaman zaman onlardan şikayet alıyorum bak bugün yine çok gerginsin cümlelerin çok olumsuz, olumsuz konuşuyorsun dedikleri oluyor, ben onlar söylediği zaman fark ediyorum. Ee sebebini düşündü̆̆̈̈mden gün içinde derslerdir okulda yaşadığım bir şeylere sabretmek zorunda kaldığım için olduğunu tahmin ediyorum. Bir takım etkileri var birçok şeye sabretmem. Ee özellikle çocuk akşam eğlenceli bir şekilde vakit geçireceksem bugün bana bulaşmayın bugün hiç tadım yok diye kenara çekiliyorum. Onlara vakit ayıramıyorum kaliteli vakit geçirmem lazım çocuğumla. Bunu biliyorum aslında vakit var ama olumsuz bir yaşamışsam çocuktan biraz uzaklaşıyorum sanırım bu erkelerde "mağaraya girme metaforu" var ya kendimi bu durumda öfkeli isem birazcık yalnızlh̆̆ı tercih ediyorum (Remzi). 
Akademide gösterilen sabrın sadece psikoloji üzerinde, beden üzerinde veya aile üzerinde etkileri yoktur. Bunların dışında doktora öğrencilerinin sosyal hayatlarında ve arkadaş ilişkilerinde de bir takım etkilerinin olduğu tespit edilmiştir. Bunlara ilişkin bilgiler aşağıdaki Tablo 12' de verilmiştir.

Tablo 12. Akademide Sabrın Sosyal Hayat-Arkadaşlar İle İlgili Etkileri

\begin{tabular}{ll}
\hline \multicolumn{1}{c}{ Sosyal Hayat-Arkadaşlar Üzerindeki Etkileri } \\
\hline & İçe kapanıklık \\
& Yalnızlaşma \\
& Hafta sonu tatillerde eve kapanma, tatillerden feragat etmek \\
& Sosyal hayatın bitmesi \\
Asosyallik & Sosyal hayattan uzaklaşmak (Ödev yapma, okumalar, makaleler zaman aldığı için \\
& sosyal hayatın azalması, kısıtlı olması, sinemaya gidememek, gezememek gibi) \\
& Mutsuzluk \\
& Bunun yaşam tarzı haline gelmesi, normalleşmesi \\
& Plan varsa onu iptal etmek \\
\hline & Çok kişiyle görüşmek istememek \\
& İnsanlarla konuşmak istememek \\
& Paylaşmak istememek \\
& Akademi dışındaki arkadaşlardan destek almak \\
& Okulda arkadaşlarla rahat konuşamama sonucunda duygulara ket vurmak \\
& Arkadaş-aile ile aranın bozulması \\
& Aile-arkadaşlarla görüşememek \\
Arkadaşlık ve & Aile-arkadaşları telefonla bile aramayı ihmal etmek \\
sosyal yaşam & Soğuk davranmak ve davranılmak \\
& Arkadaşlarla araya mesafe girmesi \\
& Bazı arkadaşlarla hiç konuşmamak \\
& Sosyal hayattan (akademideki) bazı arkadaşları çıkarmak, atmak veya zorunlu \\
& ilişki kurmak \\
\hline
\end{tabular}

Tablo 12'de görüldüğü gibi akademik sabrın doktora öğrencilerinin sosyal hayatı ve arkadaş ilişkilerini de etkilediği sonucuna varılmıştır. Sosyal hayat ve arkadaşlar üzerindeki etkileri asosyallik, arkadaşlık ve sosyal yaşam olarak iki alt kategoriye ayrılmıştır. Aşağıda bu alt kategorilere ilişkin görüşler sırasıyla verilmiştir.

*Biraz uzaklaşıyorsunuz aslında her şeyden ilişkilerinizden böyle içine kapanıklık yalnızlaşma durumu çok oluyor o yüzden çok kişiyle görüşmek konuşmak paylaşmak istemiyorsunuz içine kapanmayı tercih ediyorsunuz. İlişkilerimde kopukluk soğukluk yaşadığım oluyor (Yelda).

*Arama mesafe koyduğum arkadaşlarım oldu mesela başta hakkında iyi düşündüğüm ama akademide yaşadığım sorunlar ve sabretmem nedeniyle mesafe koyduğum hatta şuan pek konuşmayı tercih etmediğim insanlar bile var. Yani onlar benim sosyal hayatımın için de 
yoklar yani onları arkadaşlıktan çıkardım mecbur kaldığımda görüşeceğim kişiler haline geldiler ama onun dışında özel olarak sosyal hayatıma etkileri var mi.... yani oturalım birlikte film izleyelim şuraya gidelim falan yemek içmek gibi tamamen kişisel zorunlu ihtiyaçlarımı gidermem dışında, uyumak dışında sürekli çalışıyorum. Sosyal hayat diye bir şey kalmıyor ki zaten yani çok nadir bunlar tabiki sabırla ilgili yani (Aysun).

\section{Tartışma ve Sonuç}

Çalışma, eğitim fakültesinde ders alan doktora öğrencilerinin akademide yaşadıkları sabra ilişkin görüşlerini araştırmak amacıyla yapılmıştır. Doktora öğrencilerinin akademide sabır kavramını tanımlamaları neticesinde iki ana kategori oluşturulmuştur. Bunlar çözüm yolu bulma ve olayı kapatma ile eğitim kategorileridir. Akademide sabır gösterilen durumlar dersler/akademik çalışmalar, arkadaşlar, hocalar ve fiziki ortamdır. Sabır gösterme nedenleri incelendiğinde eğitim/akademik çalışmalar nedeniyle, olayı kapatmak için, mecburiyetten, öğrencinin kendi iç huzuru için, sevgi-saygı ve daha önceki tecrübeler nedeniyle olduğu tespit edilmiştir. Akademide sabır göstermenin doktora öğrencileri üzerinde psikolojik, bedensel, ailesel ve sosyal hayat/arkadaşlar ile ilgili etkileri olduğu sonucuna varılmıştır.

Sabır, bir uyarıcıyı değiştirmeyi değil, karşıdan gelen uyarıcıyı kendi lehine düzenlemeyi, ona yanıt vermeyi içerir (Schnitker \& Emmons, 2007). Sabır ile başa çıkma mekanizmaları üzerine yapılan araştırmalar da sabırsızlık durumunun hayati bir stresör olmadığını, ancak bireyin tepkilerinin önemli olduğunu bildirmektedir (Leahy, 2008). Örneğin yemek pişirirken izlenen bir tencerenin; çay yapmadan önce suyun kaynaması; sıkışan trafikte beklemek, yemek veya banka kuyrukları, hastane randevuları, randevuya geciken arkadaşlar, ertelenen sınavlar veya programlar, bir hastalığın geçmesini beklemek, belirli bir tarihi (düğün, buluşma, sınav vb) ve daha birçok örnek sabırla beklemenin önemini göstermektedir. Kişi eğer sabırlı davranmazsa gerçekten beklemeyi sıkıcı olarak deneyimleyebilir. Buna karşıllı, dikkatini saptırırsa (örneğin mutfakta başka bir şey yaparak veya arkadaş veya aile üyesi ile sohbet ederek), su daha çabuk kaynar gibi görünecektir. Kişi kendisini ders çalışmaya verirse, kısacası sabrederek, zamanını olumlu değerlendirirse durumu kendi lehine çevirebilir. Bu durumlar akademide de aynı şekildedir. Makale yazma süreci, makalenin dergiye gönderilip hakem değerlendirmelerinin beklenmesi, düzeltmeler, tekrar bekleme süreci veya doktora öğrenimi sırasında dersleri takip etme, ödevler, okumalar, tez yazarken veri toplama ve yazma süreci olduğu gibi arkadaşlar, hocalar, aileye de sabır göstermek durumunda kalınmaktadır. Kişi sabırlı davranmaz ise tabi ki bireyde bir 
takım olumsuz sonuçlarla karşılaşabilir. Bu sebeple akademide sabırlı davranmak ve ona uygun hareket etmek bireyin hem kendisi, çevresi, çalıştığ1 örgüt; hem de yaptığı ve yapacağı çalışmalar için önemli olabilir.

Comer ve Sekerka'ya (2014) göre zaman yavaş geçiyor gibi göründüğünde, sabır etme insanların istediklerini yapma veya yapma yetenekleri üzerindeki algılanan kısıtlamalarla baş etmelerine yardımcı olur. Zaman çok çabuk geçiyor gibi göründüğünde, sabır onları çoklu hedeflere ulaşma mücadelesi karşısında bunalmaya karşı koruyabilir. Öyleyse, sabrı arttırmanın anahtarı, belirli bir durumun her (veya bazen de herhangi bir) yönünü kontrol etmenin mümkün olmamasına rağmen, kişinin koşullara ilişkin algılarını ve tepkilerini kontrol etmenin mümkün olabileceğini kabul etmektir. Bu da kişinin kendisini düzenleme yoluyla (Bandura, 1991) olabilir. Öz-düzenleme, kişinin kendi üzerinde kontrolün kullanılmasıdır. Bu insanın kendisini değiştirme çabalarını, kendi içsel durumlarını veya tepkileri kapsamaktadır. Kendi kendini düzenleme, insanların uygunsuz cevapları daha etkili cevaplarla değiştirmelerini de sağlar (DeWall, Baumeister, Mead, \& Vohs, 2011; Gross, 1998). Bireyler, etkisiz ve istenmeyen durumlar için faydalı ve uygun duygusal durumları yönetmeye çalışırlar. Diğer bir deyişle, daha uyumlu bir yanıt ve yaşantı oluşturmak için öz düzenlemeyi kullanabilirler (Comer \& Sekerka, 2014). Bu da beraberinde tabiki sabrı getirmektedir.

Bireylerin sabır göstermeleri için durumsal yaklaşımlarının seçimi, kendilerini alıkoymaktan kaçınmak için adımlar atmayı içerir. Burada elbette olumsuz duygular oluşturan koşullardan kaçınmak da çok etkili olabilir. Sabır gösterirken çatışmaları en aza indirmek için örneğin, belirli bir meslektaşı ile karşılaşmamak, istenmeyen bir dedikodu ortamına maruz kalmamak için kişi alternatif bir rota seçebilir, o kişiyle karşılaşmamak için bireysel önlemler alabilir. Benzer şekilde, çalışmasının bölünmesini, görevinin kesintiye uğramasını istemeyen bir yönetici sık sık gelenlerin ziyaretlerini caydırmak için kapıyı kapatabilir. Durum seçimi, öz düzenleme stratejisi ile birlikte sabır durumunu önleyici olarak kişinin lehine çevrilebilir. Ancak, bu strateji (durum seçimi) her zaman mevcut veya uygulanabilir olmayabilir (Comer \& Sekerka, 2014). Sabırlı olma stratejileri ile ilgili Schnitker (2012) ise farklı yönlere odaklanma, zaman yönelimini azaltma, bulunulan anın tadını çıkarma, olumlu bakış açısına sahip olma veya olmaya çalışma, kısıtlamalarla başa çıkabilmek için çalışma ve açık fikirli ve esnek olma ve bunun gibi aktiviteleri önermektedir. 
Araştırma sonucunda bireylerin olumlu sonuçlarla karşılaşmaları için sabır göstermeleri, hem kendi sağlıkları, hem aile ve arkadaş ilişkileri, hem de akademik çalışmalarının kalitesi açısından önemli olduğu söylenebilir. Bu sebeple bireyler sabır etme stratejileri belirleyerek ona uygun davranabilirler. Akademide ortak yapılan çalışmalarda kişi sayısının iki olması, herkesin istediği kişi ile grup olarak çalışması iş yükünde adaleti sağlayabilir. Ders hocalarının intihal programlarına bakmaları, yapılan ödevleri titizlikle okumaları ve mutlaka geri bildirim vermeleri, danışmanı olan öğrenciler ile diğerleri arasında not verirken ayrım yapmamaları, bireysel şikâyetleri öğrencinin notuna yansıtmamaları, kendi görüşlerini içeren akademik, yanlı çalışmaları ders kapsamında sürekli olarak okutmamaları, görüşlerini derslerde tek doğruymuş gibi kabul ettirmeye çalışmamaları, doktora öğrencilerinin de sadece öğrenci olmadıkları, başka işlerinin (öğretmen gibi) ve ailelerinin de olduğunun göz önünde bulundurması akademi açısından faydalı olabilir. Lisansüstü öğrencilerine ve özellikle doktora öğrencilerine yönelik psikolojik danışmanlık sistemi üniversiteler bünyesinde başlatılabilir. Sabır etme stratejileri ile ilgili kontrol ve deney grubunu içeren deneysel çalışmalar yapılabilir. Aynı araştırma akademide sabır ölçeği geliştirilerek, tüm lisansüstü öğrencilerine uygulanarak sonuçlar genellenebilir. $\mathrm{Bu}$ çalışma akademisyenlerle veya devlet ve özel okullarda çalışan öğretmenlerle, yöneticilerle yapılabilir.

\section{Kaynaklar}

Akrivou, K., Bourantas, D., Mo, S. \& Papalois, E. (2011). The sound of silence - a space for morality?: the role of solitude for ethical decision making. Journal of Business Ethics, 1(1), 119-133.

Bandura, A. (1991). Social cognitive theory of self-regulation. Organizational Behavior and Human Decision Processes, 50(2), 248-287.

Bernard, H. R. (2011). Research methods in anthropology: Qualitative and quantitative approaches. New York: Rowman Altamira.

Blount, S. (1995). When social outcomes aren't fair: The effect of causal attributions on preferences. Organizational Behavior and Human Decision Processes, 63(2), 131-144.

Blount, S. \& Janicik, G. A. (2001). When plans change: Examining how people evaluate timing changes in work organizations. Academy of Management Review, 26(4).

Burger, J. M. \& Cooper, H. M. (1979). The desirability of control. Motivation and Emotion, 3(4), 381-393.

Charmaz, K. (2011). Grounded theory methods in social justice research. The Sage Handbook of Qualitative Research, 4, 359-380.

Comer, D. R. \& Sekerka, L. E. (2014). Taking time for patience in organizations. Journal of Management Development, 33(1), 6-23.

Creswell, J. W. (2002). Educational research: Planning, conducting and evaluating quantitative and qualitative research. New Jersey: Pearson. 
Creswell, J. W. (2007). Qualitative inquiry E research design: Choosing among five approaches. Thousand Oaks, California: Sage.

Creswell, J. W. \& Clark, V. L. P. (2016). Designing and conducting mixed methods research. New York: Sage.

Curry, O. S., Price, M. E. \& Price, J. G. (2008). Patience is a virtue: Cooperative people have lower discount rates. Personality and Individual Differences, 44, 780-785

Darley, J. M. \& Batson, C.D. (1973). From Jerusalem to Jericho: A study of situational and dispositional variables in helping behavior. Journal of Personality and Social Psychology, 27(1), 100-108.

Delongis, A., Coyne, J. C., Dakof, G., Folkman, S. \& Lazarus, R.S. (1982). Relationship of daily hassles, uplifts, and major life events to health status. Health Psychology, 1, 119-136.

DeWall, C. N., Baumeister, R. F., Mead, N. L. \& Vohs, K. D. (2011). How leaders self-regulate their task performance: evidence that power promotes diligence, depletion, and disdain. Journal of Personality and Social Psychology, 100(1), 47-65.

Doğan, M. \& Gülmez, Ç. (2014). Sabır ölçeğinin Türkçe'ye uyarlanması: Geçerlik ve güvenirlik çalışması. Atatük Üniversitesi İlahiyat Fakültesi Dergisi, 42, 263-279.

Doğan, M. (2014). Dindarlık sabır ve psikolojik iyi olma arasındaki ilişkiler (Yayımlanmamış doktora tezi). Atatürk Üniversitesi, Erzurum.

Dudley, K. C. (2003). Empirical development of a scale of patience (Unpublished doctoral dissertation). West Virginia University, Morgantown, West Virginia.

Eddles-Hirsch, K. (2015). Phenomenology and educational research. International Journal of Advanced Research, 3(8), 251-260.

Eliüşük, A. (2014). Sabır eğiliminin öz-belirleme, öz-anlayış ve kişilik özellikleri açısından incelenmesi (Yayımlanmamış doktora tezi). Necmettin Erbakan Üniversitesi, Konya.

Ersoy, A. (2016). Fenomenoloji. Eğitimde nitel araştırma desenleri. A. Saban ve A. Ersoy, (Edt). Ankara: Anı.

Gross, J. J. (1998). The emerging field of emotion regulation: an integrative review. Review of General Psychology, 2(3), 271-299.

Kıral, B. (2008). Ortaöğretim okul yöneticilerinin yaşadıkları stres belirtileri düzeyi (Yayımlanmamış yüksek lisans tezi). Kırıkkale Üniversitesi, Kırıkkale.

Lavelock, C. (2013). Four virtues: Interventions for goodness' sake (Unpublished master thesis). Virginia Commonwealth University, Richmond, Virginia.

Leahy, L. (2008). Surviving change. Strategic HR Review, 7(6), 23-29.

Lincoln, Y. S. \& Guba, E. G. (1986). But is it rigorous? Trustworthiness and authenticity in naturalistic evaluation. New Directions for Evaluation, 30, 73-84.

Lopez, K. A. \& Willis, D. G. (2004). Descriptive versus interpretive phenomenology: Their contributions to nursing knowledge. Qualitative Health Research, 14(5), 726-735.

Marshall, C. \& Rossman, G. B. (2014). Designing qualitative research. New York: Sage.

Merriam, S. M. 2009. Qualitative research: A guide to design and implementation. San Fransisco, CA: John Wiley \& Sons Inc.

Miles, M. B. \& Huberman, A. M. (1994). Qualitative data analysis. Thousand Oaks, Sage.

Moustakas, C. (1994). Phenomenological research methods. Thosand Oaks: Sage.

Morgan, D. L. \& Morgan, R. K. (2008). Single-case research methods for the behavioral and health sciences. Thousand Oaks, California: Sage

Music, D. (2013). Patience in group decision-making with emotional agents. Trends in practical applications of agents and multiagent systems. J. B. Pérez, J. M. C. Rodríguez, J. Fähndrich, P. Mathieu, A. Campbell, M. C. Suárez-Figueroa, E. Adam, 
Fernández Caballero, R. Hermoso, M. N. Moreno (Edts.). (pp.163-170). Switzerland: Springer International Publishing

Okçu, D. \& Pilatin, U. (2018). Ortaokul öğrencilerinin sabır değeri ile ilgili algılarının resim yoluyla değerlendirilmesi. Batman Üniversitesi İslami İlimler Fakültesi Hakemli Dergisi, 2(1), 102-113.

Onwuegbuzie, A. J. \& Collins, K. M. (2007). A typology of mixed methods sampling designs in social science research. The Qualitative Report, 12(2), 281-316

Oxford Sözlük. (2019). https://en.oxforddictionaries.com. Erişim tarihi: 20.05.2019.

Özdemir, N. (2018). Engelli ailelerinde problem çözme ve sabır gösterme davranışları arasındaki ilişkinin incelenmesi (Yayımlanmamış yüksek lisans tezi). İstanbul Ticaret Üniversitesi, İstanbul.

Patton, M. Q. (2014). Qualitative research and evaluation methods. Edts: M. Butun \& S. B. Demir. Ankara: PegemAkademi.

Pearson, C.M. \& Porath, C.L. (2005). On the nature, consequences and remedies of workplace incivility: no time for 'nice'? Think twice. Academy of Management Executive, 19(1), 7-18.

Polkinghorne, D. (1989). Phenomenological research methods. In R. Valle \& S. Halling (Eds.), Existential phenomenological perspectives in psychology: Exploring the breadth of human experience (41- 60). New York: Plenum.

Rubin, A. \& Babbie, E. R. (2016). Empowerment series: Research methods for social work. Boston: Cengage Learning.

Schnitker S. A. (2012). An examination of patience and well-being. The Journal of Positive Psychology: Dedicated to furthering research and promoting good practice, 7(4), 263-280.

Schnitker, S. A. \& Emmons, R.A. (2007). Patience as a virtue: Religious and psychological perspectives. Research in the Social Scientific Study of Religion, 18, 177-207.

Sekerka, L. E. \& Zolin, R. (2007). Rule-bending: Can prudential judgment affect rule compliance and values in the workplace?. Public Integrity, 9(3), 225-243.

Tasavvuf Terimleri ve Deyimleri Sözlüğü. (1997). Haz.: E.Cebecioğlu. İstanbul: Anka.

Türk Dil Kurumu Sözlüğü. (2019). http://www.tdk.gov.tr_Erişim tarihi: 20.05.2019.

Yıldırım, A. \& Şimşek, H. (2005). Sosyal bilimlerde nitel araştırma yöntemleri. Ankara: Seçkin.

Yin, R. K. (2011). Qualitative research from start to finish. New York: The Guilford Press. 